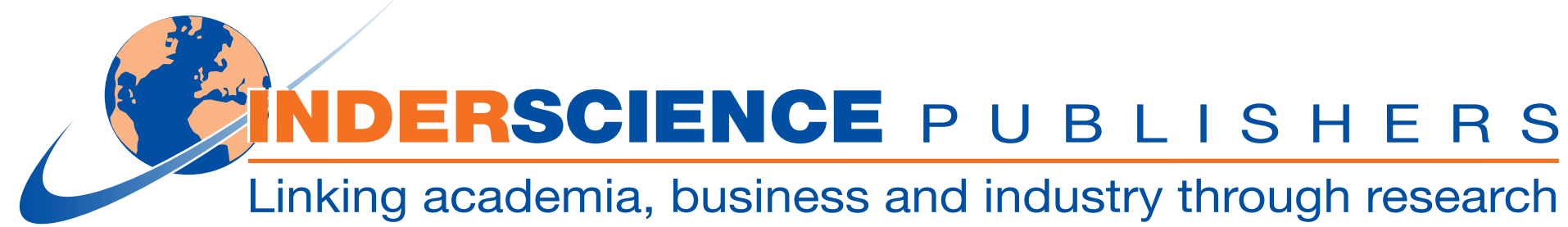

$\underline{\text { Home }}>$ International Journal of Business Governance and Ethics

\section{International Journal of Business Governance and Ethics}

This journal also publishes Open Access articles

\section{Editor in Chief}

Dr. Stuart Farquhar

\& Ethics

\section{ISSN online}

$1741-802 X$

ISSN print

1477-9048

4 issues per year

Calls for papers

Subscription price

As the world becomes increasingly dominated by interconnected corporations alongside increasing demands for transparency and accountability, business governance is no longer just about running companies and organisations efficiently, but about managing wider responsibilities. Company directors need to move beyond governance concerns that deal with their functional responsibilities towards understanding how their personal values and actions affect the organisations they lead, and how in turn these affect local and global communities. IJBGE provides a professional forum to address these issues.
Sign up for new issue alerts

$\underline{\text { Subscribe/buy articles/issues }}$

View sample issue

Latest issue contents as RSS feed ה

Forthcoming articles

Journal information in easy print format (PDF)

Publishing with Inderscience: ethical guidelines (PDF)

View all calls for papers

Recommend to a librarian (PDF)

Feedback to Editor

Find related journals

\section{Keep up-to-date}

S Our Blog

(9) Follow us on Twitter

f Visit us on Facebook

G. Join us on Google+

:

. RSS Feeds

New issue alerts 


\section{Inderscience Publishers: Article accepted for publication - IJBGE-9819}

1 messaggio

Inderscience Submissions <no-reply@indersciencesubmissions.com>

A: marina.brogi@uniroma1.it, valentina.lagasio@uniroma1.it

Cc: marina.brogi@uniroma1.it

11 dicembre 2018 11:11

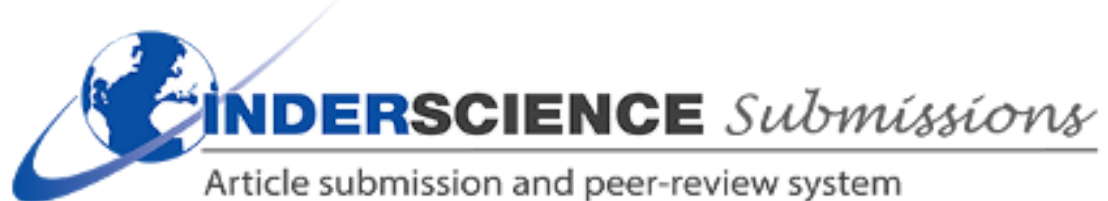

Dear Dr. Valentina Lagasio,

(Co-authors, you are copied into this email for information purposes only.)

Ref: Article title: "The big bank theory. Into the bank Corporate Governance literature."

Submission code: IJBGE-9819

I am pleased to inform you that your article has been accepted for publication in Int. J. of Business Governance and Ethics.

You now need to upload the final revised version for this article and your author copyright agreement form(s) or your Open Access order form.

The reviewers' comments are added to the end of this email for your information. There may be some useful suggestions for improving your final version.

\section{* INSTRUCTIONS *}

Log in to the Inderscience Submissions system. There is a reminder facility there if you have forgotten your username or password.

Then click on the following link, and you will be taken to the correct section for uploading:

https://indersciencesubmissions.com/track/index. php?action=submissiondetails\&intSubmissionld=9819

1. Scroll down the page to the section called "Peer Review Progress".

Click on "Edit metadata" to make any required corrections to the title, abstract or keywords. Please also review carefully for any spelling or grammatical errors.

Remember to click the "Submit" button to save your changes.

2. Returning to the "Peer Review Progress section", at the "Type of Article" drop-down list, select whether the article is a "Standard" article (the default) or an "Open Access" article.

If you are submitting an Open Access article, you will need to upload a completed OA order form. (See more information on the Inderscience web site at http://www.inderscience.com/info/inauthors/author_oa.php )

Select the Licence Type, and then move onto point 4 on this list.

3. For Standard articles, use the "Browse" or "Choose file" button to locate and insert your signed Author Copyright Agreement Form.

If there is more than one author, please submit forms all together in a zipped file. We must receive a signature from every author on a separate form. 
It is not acceptable for one author to sign on behalf of the other authors.

The Author Copyright Agreement Form (and instructions on how to sign and submit it) can be found on the Inderscience website at

http://www.inderscience.com/info/inauthors/author_copyright.php

If you are submitting an Open Access article, you do not need to submit a copyright agreement form.

4. Next you need to insert the final version of your article.

Right-click on the file name next to "Author's original submission", or "Author's revised submission" if you previously made changes, and save it on your computer.

Open this file and remove your reply or any response to reviewers that might show at the beginning of your article.

Re-insert any author details, such as name, email addresses, institution and biographical statements in the first page of your file.

Save your changes and rename the file "authorFinalVersion.doc" or "authorFinalVersion.docx".

No other files types are accepted.

(if this is a LaTeX file, please upload a pdf version as a supplementary file).

Now return to our submissions system, and use the "Browse" or "Choose file" button to insert this file.

5. Check that you have done all 4 steps as indicated above and then click the "Upload" button to submit the final version of your article and accompanying documents.

Thank you! Your continuing cooperation is most appreciated.

With kind regards,

Dr. Stuart Farquhar (Editor)

Int. J. of Business Governance and Ethics

http://www.inderscience.com/IJBGE

\section{REVIEWER 1}

REVIEW COMMENTS:

Changes which must be made before publication:

None

Suggestions which would improve the quality of the article but are not essential for publication: None

REVIEWER 2

REVIEW COMMENTS:

Changes which must be made before publication:

Acceptable

Suggestions which would improve the quality of the article but are not essential for publication: Acceptable

\section{* End of reviewer comments *}




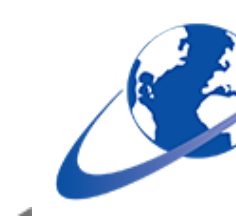

Inderscience Submissions Dashboard

Article submission and peer-review system
Support \& Documentation
Logged in as valentina.lagasio@uniroma1.it

[Log out]

Welcome > Your Submissions > IJBGE-9819

Need help?

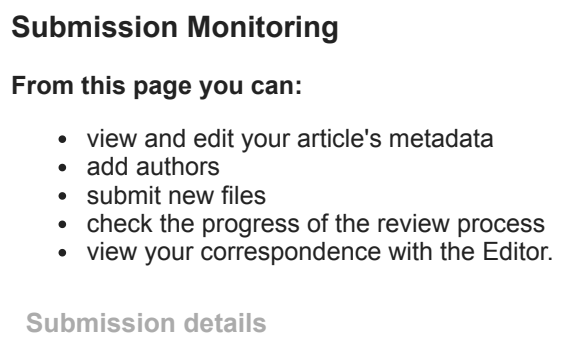

Author to Typesetter for Amends

Submission ID: IJBGE-9819

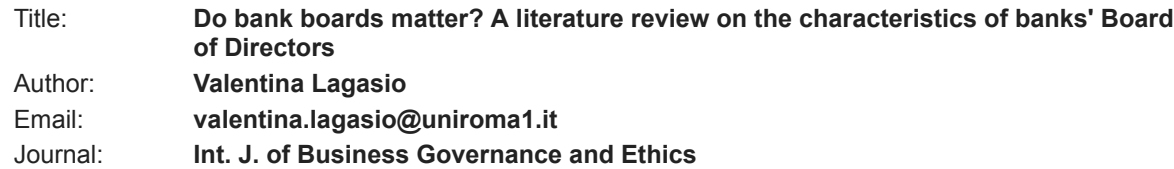

Author's final version:

Supplementary File: 2018_IJBGE_9819_sup5314.pdf [11 Dec 2018] $\quad$ \

Add Supplementary Files

Typesetter invites the Author to check the proof

You have uploaded your annotated proof files.

You will receive an email telling you when the final proof is ready for you to check.

Article received from Typesetter for first proof:

Proof reply send to Typesetter:

2018_IJBGE_9819_TAV.pdf

[20 Dec 2018]

1st Amendment Sheet:

2018 IJBGE 9819 ATV.pdf

[20 Dec 2018]

2018_IJBGE_9819_ATVAS1.docx

[20 Dec 2018]

Author - Editor / Typesetter Communication

Post Comment to Typesetter

Post Comment to Editor

From

To

Dr. Valentina

Lagasio [ Author ]

Allset Allset

Valentina Lagasio

Author ]

Allset Allset

Inderscience
[ Typesetter: Allset Allset ]

[ Editor: Stuart Farquhar ]

Email/Comments

Date Sent

Inderscience Publishers:

IJBGE-9819 comment from 08 Jan 2019

Valentina Lagasio

IJBGE-9819: Notification

about uploaded amended 20 Dec 2018

paper

Inderscience Publishers:

20 Dec 2018 
Submissions

Inderscience

Submissions [

Editor ]

Dr. Stuart

Farquhar [ Editor ]

Dr. Valentina

Lagasio [ Author ]

Inderscience

Submissions [

Author ]

Inderscience

Submissions [

Editor ]

Dr. Stuart

Farquhar [ Editor ]

Dr. Valentina

Lagasio [ Author ]

Dr. Stuart

Farquhar [ Editor ]

Dr. Valentina

Lagasio [ Author ]

Dr. Valentina

Lagasio [ Author ]

Dr. Stuart

Farquhar [ Editor ]

Dr. Valentina

Lagasio [ Author ]

Dr. Valentina

Lagasio [ Author ]

Inderscience

Submissions

Manager

Inderscience

Submissions

Manager
Marina Brogi,Valentina Lagasio [

Author ]

Valentina Lagasio [ Author ]

Stuart Farquhar [ Editor ]

Stuart Farquhar [ Editor ]

Valentina Lagasio [ Author ]

Valentina Lagasio [ Author ]

Stuart Farquhar [ Editor ]

Valentina Lagasio [ Author ]

Stuart Farquhar [ Editor ]

Stuart Farquhar [ Editor ]

Valentina Lagasio [ Author ]

Stuart Farquhar [ Editor ]

Stuart Farquhar [ Editor ]

Valentina Lagasio [ Author ]

Valentina Lagasio [ Author ]
IJBGE-9819 -your article

proofs are ready to check

Inderscience Publishers:

Article accepted for

publication - IJBGE-9819

Inderscience Publishers:

IJBGE-9819 - comment from 06 Dec 2018

Stuart Farquhar

Inderscience Publishers:

IJBGE-9819 comment from 05 Dec 2018

Valentina Lagasio

Inderscience Publishers:

IJBGE-9819 Revised article 14 Oct 2018

uploaded

Inderscience Publishers:

IJBGE-9819 : Request to

revise your article

Inderscience Publishers:

IJBGE-9819 - comment from 14 Sep 2018

Stuart Farquhar

Inderscience Publishers:

IJBGE-9819 comment from 05 Sep 2018

Valentina Lagasio

Inderscience Publishers:

IJBGE-9819 - comment from 11 Jul 2018

Stuart Farquhar

Inderscience Publishers:

IJBGE-9819 comment from

10 Jul 2018

Valentina Lagasio

Inderscience Publishers:

IJBGE-9819 comment from 20 Apr 2018

Valentina Lagasio

Inderscience Publishers:

IJBGE-9819 - comment from 20 Apr 2018

Stuart Farquhar

Inderscience Publishers:

IJBGE-9819 comment from 20 Apr 2018

Valentina Lagasio

Inderscience Publishers:

IJBGE-9819 comment from 11 Apr 2018

Valentina Lagasio

Inderscience Publishers:

IJBGE-9819 - Article entering 21 Feb 2018

review process

Inderscience Publishers:

IJBGE-9819 - Submission 20 Feb 2018

Acknowledgement

Legends: Delete $\$ Edit Download

Contact us I About Inderscience | OAI Repository | Privacy and Cookies Statement | Terms and Conditions | C Inderscience Enterprises Ltd. 2019 


\title{
Do bank boards matter? A literature review on the characteristics of banks' board of directors
}

\section{Marina Brogi and Valentina Lagasio*}

Management Department,

Faculty of Economics,

Sapienza University of Rome, Italy

Email: marina.brogi@uniroma1.it

Email: valentina.lagasio@uniroma1.it

*Corresponding author

\begin{abstract}
Corporate governance of banks is important and unique (Levine, 2004). Sound bank corporate governance is a crucial element for promoting a more resilient financial system (FSB, 2013) and sustaining economic growth (BCBS, 2015). A systematic literature review is conducted on the articles published in peer-reviewed academic journals to identify the prevailing results in academic research on bank board characteristics, which is the most investigated topic in bank corporate governance. Based on both theoretical and empirical contributions, findings show that research mainly measures the impact of board characteristics on performance and risks potentially faced by banks, however there is no univocal consensus on the best practices to adopt. Further research is needed to directly investigate other areas of bank corporate governance (such as internal risk management, remuneration and ownership structure).
\end{abstract}

Keywords: banks; corporate governance; board of directors; BoD; board independence; review.

Reference to this paper should be made as follows: Brogi, M. and Lagasio, V. (xxxx) 'Do bank boards matter? A literature review on the characteristics of banks' board of directors', Int. J. Business Governance and Ethics, Vol. x, No. $\mathrm{x}, \mathrm{pp} . \mathrm{xxx}-\mathrm{xxx}$.

aphical notes: 
This paper is a revised and expanded version of a paper entitled [title] presented at 2 , location and date of conference].

\section{Introduction}

"Alongside adequate capital and organisation, the third factor of the stability of the banking system is the quality of corporate governance" (Draghi, 2008). Soundness of the financial and banking system underpins economic growth by ensuring an effective and efficient allocation of resources (Levine and Zervos, 1998; Beck et al., 2000; Levine et al., 2000; Claessens and Laeven, 2003) and exerting an important influence on corporate governance of firms (Franks and Mayer, 2001; Santos and Rumble, 2006; Dika et al., 2013). Indeed, as further investigated in this paper, both academics and practitioners, claim that failures and weaknesses of bank corporate governance greatly contributed, the financial crisis that commenced in 2007 and plagued the economy until the recent years (Kirkpatrick, 2009; a'eed, 2012). As a matter of fact, several studies support the need for banks to be sct to specific governance provisions due to the complex and opaqueness of their business (Caprio and Levine, 2002; Levine, 2004; Macey and O'Hara, 2003; Brogi, 2008). Bank corporate governance indeed appears to be different from that of other firms (Hopt, 2013; Becht et al., 2011; Mehran et al., 2011), therefore financial intermediaries are unique also from a corporate governance perspective (Llewellyn, 2002). While there is a growing body of literature on governance of financial institutions there is notably a lack of a comprehensive vision of the topic (Macey and O'Hara, 2003; $\square$ ns and Mehran, 2005; Caprio et al., 2007). Furthermore, there is a striking gap b $\mathrm{n}$ the perspective of regulators and supervisors and main academic researches and findings. In order to assess to what extent academic knowledge supports decisions taken by regulators and supervisors we first examine the academic debate concerning bank corporate governance by conducting a systematic literature review on 120 scholarly publications in the period from 1980 (first paper included in the sample) to 2015, selected among peer-reviewed academic lals. This paper speaks to the call by Macey and O'Hara (2003), Adams and ran (2005) and Caprio et al. (2007) for a better understanding of the specific issues of bank corporate governance development and tries to shed some light on the causality dilemma between theory and practice, by investigating whether or not the progress of regulation and supervision in the area of bank governance follows academic findings. Hence, this research balances theoretical and empirical contributions in corporate governance literature, moreover findings of this paper have relevant policy implications by making a clear and concrete contribution on the on-going debate on bank corporate governance. The main findings of this paper lead to assert that there is an increasing understanding of the fundamentals of bank corporate governance even though there is still no univocal consensus on the best practices to adopt in order to improve bank performance and effectively manage bank risk. Despite difficulties in defining an ideal board structure, authorities have introduced several provisions with the aim of strengthening risk management regulation, and assessing the accuracy and usefulness of information provided to and from banks' directors also by engaging more frequently with board and management. Notwithstanding this, standard setters and regulators tend to focus respectively on what the board should do and must do and the necessary 
competences of board members as opposed to structural characteristics (BCBS, 2010; FSB, 2013; Directive 2013/36/EU or CRD IV; Bank of Italy, 2013; Brogi, 2011). In this paper, we focus on the literature on bank board characteristics because we found it to be the prevailing topic in the bank corporate governance literature. Nonetheless, researchers should also further investigate internal risk management, remuneration and ownership structure in banks. The remainder of this paper is organised as follows: in Section 2, corporate governance is broadly defined to include the interface between economic and financial environment; the method used to conduct the research and the composition of the sample is described in Section 3; Section 4 presents a review of the relevant literature on corporate governance in banking and compares it with the regulatory and supervisory provisions to contribute to the ongoing debate on the topic starting from the board structure; finally in Section 5 are the policy implications as well as provocative areas for future research are discussed.

\section{Corporate governance}

Corporate governance can be broadly defined as processes and relations by which firms are managed. A first definition of corporate governance is given by Prowse (1998): "Corporate governance is rules, standards and organisations in an economy that governs the behaviour of corporate owners, directors, and managers and define their duties and accountability to outside investors, i.e., shareholders and lenders."

A more detailed definition of corporate governance is provided by the OECD: "Corporate governance involves a set of relationships between a company's management, its board, its shareholders and other stakeholders. Corporate governance also provides the structure through which the objectives of the company are set, and the means of attaining those objectives and monitoring performance are determined" (OECD, 2004, 2015). In short, corporate governance arrangements allocate rights and responsibilities among agents of every firms and affected stakeholders [e.g., board of directors $(\mathrm{BoD})$, executive managers, shareholders, and regulators]. Indeed, much of the contemporary debate regarding corporate governance has been focused on how to deal with conflicting stakeholder interests. The latter have given rise to different theories that are the object of on-going debates for both academics and regulators [in particular: agency theory (Jensen and Meckling, 1976; Eisenhardt, 1989; Yermack, 1996; Eisenberg et al., 1998); resource-based view (Mahoney and Pandian, 1992; Peteraf, 1993; Wernerfelt, 1995; Coff, 1999); transaction costs theory (Williamson, 1979, 1981); stakeholders' theory (Freeman, 1984); stewardship theory (Donaldson and Davis, 1990, 1991, ; Davis et al., 1997)].

A: cerns the institutional debate on corporate governance, though regulations vary worldwide, general, non-binding principles have been issued by various international organisations (Brogi, 2008) (such as stock exchanges, international organisations, associations, institutional investors mainly) in the last two decades in co-operation with governments of different countries, referred to both listed and unlisted companies. The most relevant principles have been issued by the committee on the financial aspects of corporate governance $\square$ Cadbury Report, 1992); The Organisation for Economic Co-operation and De sment (OECD) [Principles of corporate governance (originally developed in 1999, then updated in 2004 and finally revised in 2015 with the co-operation of G20 organisation)]; The Federal Government 
in the USA (Sarbanes, 2002); the European Commission (EC) [the commission recommendation on the role of non-executive or supervisory directors of listed companies and on the committees of the (supervisory) board 2005/162/EC] and the UK Government (2010).

In particular OECD principles are aimed to preserve the basis for an effective corporate governance framework; outline the rights and equitable treatment of shareholders and key ownership functions; define the role of stakeholders in corporate governance, the role of disclosure and transparency in perceiving the companies' objectives and the responsibilities of the board (OECD, 2004, 2015).

Financial institutions require a distinct analysis of corporate governance issues (Adams and Mehran, 2003; Macey and O'Hara, 2003) as well as specific regulatory measures due to the complexity and opaqueness of their business (Levine, 2004; Mehran et al., 2011). A broad description of banking activities concerns in credit allocation and financial services provision in order to reduce transaction costs and asymmetric information (Bhattacharya and Thakor, 1993; Allen and Santomero, 2001). They also play a decisive role in the corporate governance of other firms (Franks and Mayer, 2001; Santos and Rumble, 2006; Dika et al., 2013) by overseeing investment decisions. To sum up, Caselli (2010) argues that "governance and strategy takes place in a broad perspective in which banks and the financial system have to deal with five significant factors today: regulations, customers, knowledge, capital and synergies." As a matter of fact, when banks are efficient, they facilitate growth and stability for the economy as a whole by ensuring an effective and efficient resource allocation (Levine and Zervos, 1998; Beck et al., 2000; Levine et al., 2000; Claessens and Laeven, 2003; Kyereboah-Coleman and Biekpe, 2006).

The unique characteristics of financial intermediaries also encompass their corporate governance (Llewellyn, 2002). Indeed, OECD Principles have also been adopted as one of the Financial Stability Board's (FSB) Key Standards for sound financial systems serving FSB, G20 and OECD members; have been used by the World Bank Group and are an effective tool for implementation of the guidelines on corporate governance of banks issued by the BCBS (OECD, 2004, 2015; BCBS, 2015).

In particular, the BCBS (2015) has recently provided a definition of bank corporate governance that broadly describes the role of corporate governance from bankers' perspective: "Corporate governance determines the allocation of authority and responsibilities by which the business and affairs of a bank are carried out by its board and senior management" ("Corporate governance determines the allocation of authority and responsibilities by which the business and affairs of a bank are carried out by its board and senior management [...]"), including how they: set the bank's strategy and objectives; select and oversee personnel; operate the bank's business on a day-to-day basis; protect the interests of depositors, meet shareholder obligations, and take into account the interests of other recognised stakeholders; align corporate culture, corporate activities and behaviour with the expectation that the bank will operate in a safe and sound manner, with integrity and in compliance with applicable laws and regulations; and establish control functions. Basel Committee on Banking Supervision (BCBS), corporate governance principles for banks, July 2015.

Moreover, the EC and the EBA (2011) have developed a new regulatory framework to implement these new standards in the European Union (EU) (Regulation (EU) No. 575/2013 also known as CRR and directive 2013/36/EU or CRD IV). 
The following section shows the procedure run to assess the review and describes the main characteristics of the sample.

\section{Methodology and population of the sample}

\subsection{Methodology}

Consistent with prior systematic assessments of governance literature (e.g., Pugliese et al., 2009; Abatecola et al., 2013) the selection process is performed as follows:

1 Choose Scopus and ScienceDirect as research databases.

2 Select all articles published in journals with a peer reviewed evaluation process, written in English language thereby excluding books, chapters in books, conference proceedings, working papers and other unpublished works so as to ensure the comparability of the contents.

3 Ensure substantive relevance of the potential articles by looking for the combination of 'corporate governance' and ('banks' or 'financial institutions') in the keywords of the articles.

4 Ensure relevance of the articles by reading all abstracts checking for a discussion related to bank corporate governance following the 'fit for purpose' approach by Boaz and Ashby (2003) and $\neg$ er et al. (2008). Survey remaining articles by a complete reading in order to $\mathrm{k}$ substantive relevance for a discussion related to bank corporate governance.

5 Consolidate results.

This leads to identify a sample of articles published in top finance and management journals [American Economic Review (AER); Applied Economics Letters (AEL); Applied Financial Economics (AFE); Banca Impresa Societá (BIS); Business Strategy \& The Environment (BSE); Contemporary Economics (CE); Corporate Governance: An International Review (CGIR); Corporate Ownership \& Control (COC); Economic Modeling (EM); Economic Policy Review (EPR); Emerging Markets Review (EMR); European Economic Review (EER); European Journal Economics (EJE); European Journal of Law \& Economics (EJLE); Financial Management (FM); International Journal of Business \& Management (IJBM); International Journal of Economics \& Finance (IJEF); International Journal of Managerial Finance (IJMF); International Review of Economics \& Finance (IREF); International Review of Financial Analysis (IRFA); Journal of Accounting \& Economics (JAE); Journal of Banking and Finance (JBF); Journal of Business \& Social Sciences (JBSS); Journal of Business Ethics (JBE); Journal of Business Finance \& Accounting (JBFA); Journal of Corporate Finance (JCF); Journal of Corporate Law Studies (JCLS); Journal of Economics \& Business (JEB); Journal of Economics \& Finance (JEF); Journal of Financial \& Quantitative Analysis (JFQA); Journal of Financial Economics (JFE); Journal of Financial Intermediation (JFI); Journal of Financial Research (JFR); Journal of Financial Services Research (JFSR); Journal of Financial Stability (JFS); Journal of International Business Studies (JIBS); Journal of International Money \& Finance (JIMF); Journal of Law \& Economics (JLE); Journal of Management \& Governance 
(JMG); Journal of Monetary Economics (JME); Journal of Money, Credit \& Banking (JMCB); Journal of Risk Management in Financial Institutions (JRMFI); Pacific Basin Finance Journal (PBFJ); Quarterly Review of Economics \& Finance (QREF); Review of Economic Perspectives (REP); Review of Economics \& Statistics (RES); Review of Finance (RF); Review of Financial Economics (RFE); Review of Financial Studies (RFS); The Accounting Review (AR); The Journal of Finance (JF)] from 1980 to 2015. Furthermore a content analysis is then run following Insch et al. (1997), Bos and Tarnai (1999) and Guthrie et al. (2004) so as to analyse the development of research on bank corporate governance, by classifying all basic elements of each paper:

1 type of article

2 impact factor of the journal and cites of the article

3 main research topic and research question(s)

4 dataset, period of observation and geographical setting

5 methodology, including variables and robustness checks

6 result(s) and conclusion(s).

\subsection{Population of the sample}

The research conducted on the whole set of articles, outlined that the attention regarding banking corporate governance is mainly focused on risks potentially faced by banks and their performance capability.

The most frequent topics in the bank corporate governance literature are board structure, risk management, executive compensation, ownership structure that are normally investigated considering their impact on risks and performance drivers. In particular, as revealed by FSB (2013) board structure covers the functions and responsibilities of the board in ensuring that the "firm has an appropriate risk governance framework given the firm's business model, complexity and size which is embedded into the firm's risk culture." Risk management function is responsible for identifying, measuring, monitoring, and recommending strategies to control and mitigate risks. It also reports on risk exposures of firms, so as to ensure a risk profile in line with the risk appetite framework (RAF) approved by the BoDs. As concerns executive compensation, it is related with risk since an inadequate compensation structure may lead to excessive risk-taking. Finally, there is a wide strand of literature that relates risk and performance to the ownership structure and its concentration. Thus, breakdown based on the main research direction presented in each paper, leads to identify four main areas of interest Table 1: board structure (46 papers, corresponding to $32 \%$ of the sample); risk management $(39,27 \%)$; ownership structure $(32,22 \%)$; compensation $(26$, $18 \%)$.

Moreover, the most cited articles for each of the topics, are respectively Macey and O'Hara (2003) published in Economic Policy Review with 618 cites on Google Scholar; Barth et al. (2004) in Journal of Financial Intermediation with 1,785 cites

ch is also the most cited article in the full sample), $\longrightarrow$ bas (2001) and Berger

5b) in Journal of Money, Credit \& Banking with 55( 756 cites, respectively. Table 2 shows the 30 journals which have been most cited in bank corporate governance 
articles, considering average citations per article. The journal that received the highest average citations is Journal of Financial Economics, that published four articles on bank corporate governance. Conversely, Journal of Banking \& Finance published the largest number of articles on bank corporate governance, 32, with 150 average citations per article considering year of publication. Geographical setting reveals that the majority of articles (45\%) covers a sample of International banks, $26 \%$ is based on US banks, $13 \%$ on European banks, $11 \%$ on Asian banks and $5 \%$ of the articles in the sample are conducted on African banks (Figure 1).

Table 1 Composition of the sample

\begin{tabular}{lcc}
\hline Topic & No. of articles & No. of articles (\%) \\
\hline Board structure & 46 & $32 \%$ \\
Risk management & 39 & $27 \%$ \\
Ownership & 32 & $22 \%$ \\
Compensation & 26 & $18 \%$ \\
Total & 143 & \\
\hline
\end{tabular}

Source: Authors' own elaboration

Figure 1 Research setting (see online version for colours)

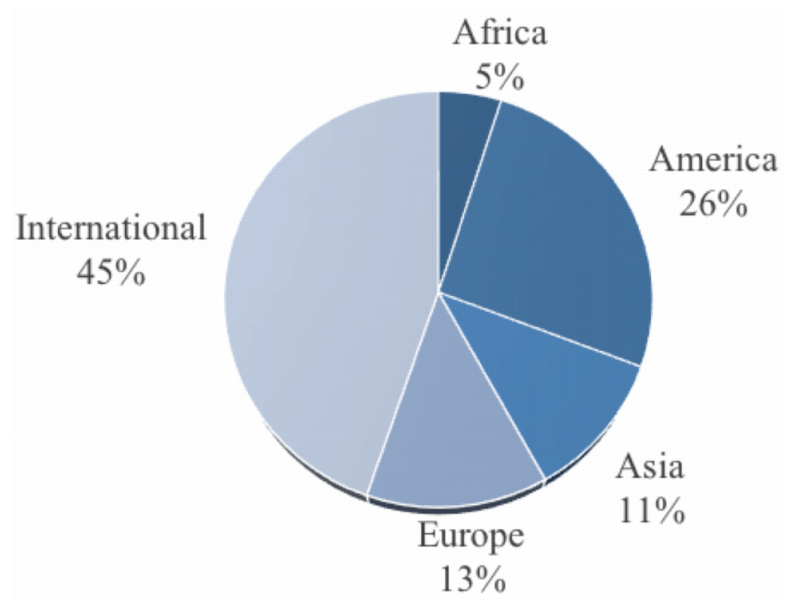

Source: Authors' own elaboration

Figure 2 shows the breakdown of different topics by geographical setting. In particular, it is notable a larger focus on compensation in US and international samples of banks (respectively of $7 \%$ and $6 \%$ of the full sample of articles). This could be a result deriving from the largest distribution of data regarding US banks compared with other Continents. Figure 3 shows the historical development in bank corporate governance literature, broken down by topic. As above mentioned the first article included in the sample has been published in 1980, hence the period of this analysis covers the period 1980-2015. As illustrated in the figure, bank corporate governance has become an 
increasingly important area for research in the last decade, especially as a reaction to the last financial crisis. Starting from 2008 the number of articles increased over time with two major peaks in 2011 and 2013. In particular, noteworthy is the increasing interest on board structure since the financial crisis, in line with the general historical development on bank corporate governance. contrariwise, compensation appears to be a hot topic for researchers in two waves, in the period 1993-1997, and in 2011-2015, when the literature starts to depict executive compensation as one of the causes of the financial crisis of 2007, due to its link with excessive risk-taking enbrach and Stulz, 2009; Beltratti and Stulz, 2009; $>$ oung et al., 2009; $\longrightarrow$ ns e 2009 ).

Figure 2 Topics by geographical setting (see online version for colours)

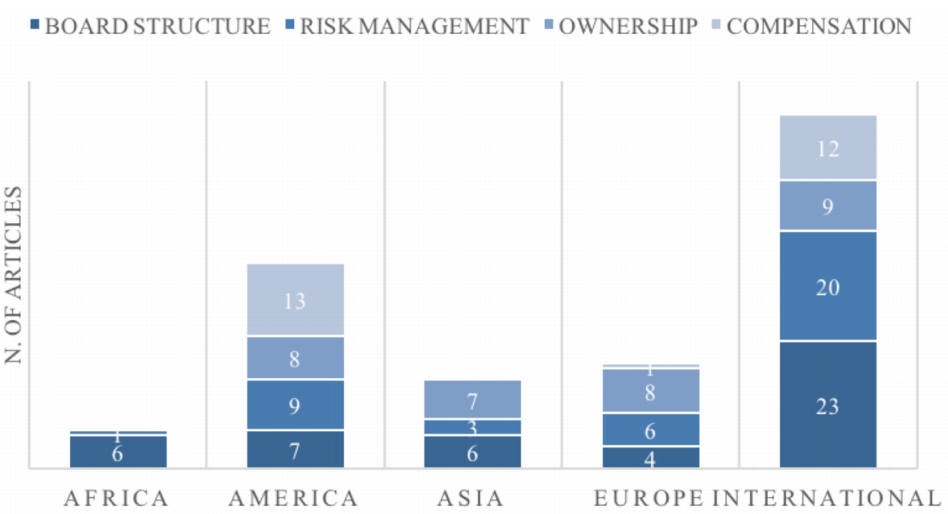

Source: Authors' own elaboration

Figure 3 Topics by year of publication (see online version for colours)

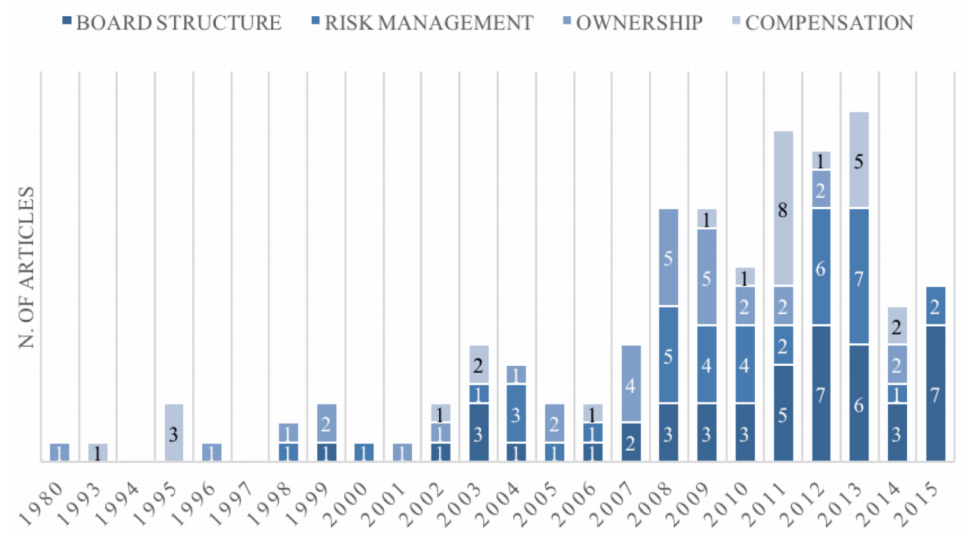

Source: Authors' own elaboration

As a matter of fact, academic literature still presents mixed result, furthermore, "there exist fundamental risk-incentive mechanisms that operate in exactly the opposite direction" (Boyd and De Nicolo, 2005). Furthermore, the diversity among financial 
system institutions lead to different risks faced by banks, supporting the unlikeliness to apply a single instrument of financial stability policy (Ellis et al., 2014).

Table 2 Top 30 cited journal in bank corporate governance

\begin{tabular}{|c|c|c|c|c|}
\hline Journal & No. of articles & $\begin{array}{c}\text { Total cites } \\
\text { (Google Scholar) }\end{array}$ & $\begin{array}{l}\text { Average of cites } \\
\text { (Google Scholar) }\end{array}$ & $\begin{array}{l}\text { Std. dev. of cites } \\
\text { (Google Scholar) }\end{array}$ \\
\hline JFE & 4 & 3,129 & 782 & 316 \\
\hline$J M C B$ & 2 & 1,322 & 661 & 95 \\
\hline$E P R$ & 4 & 1,482 & 371 & 215 \\
\hline$J F E$ & 4 & 1,359 & 340 & 377 \\
\hline$J F I$ & 8 & 2,555 & 319 & 574 \\
\hline$J M E$ & 3 & 793 & 264 & 71 \\
\hline$I R E F$ & 1 & 162 & 162 & - \\
\hline$J B F$ & 32 & 4,801 & 150 & 152 \\
\hline$J F Q A$ & 2 & 250 & 125 & - \\
\hline$F M$ & 1 & 120 & 120 & - \\
\hline$J C F$ & 7 & 680 & 97 & 114 \\
\hline$I J M F$ & 2 & 186 & 93 & 55 \\
\hline$J E F$ & 1 & 85 & 85 & - \\
\hline$J F S$ & 2 & 164 & 82 & 73 \\
\hline RES & 1 & 82 & 82 & - \\
\hline$J F R$ & 2 & 161 & 81 & 48 \\
\hline$A F E$ & 1 & 79 & 79 & - \\
\hline$J I M F$ & 1 & 75 & 75 & - \\
\hline$R F E$ & 1 & 70 & 70 & - \\
\hline$A R$ & 1 & 69 & 69 & - \\
\hline$J L E$ & 1 & 68 & 68 & - \\
\hline$J E B$ & 4 & 259 & 65 & 56 \\
\hline$P B F J$ & 2 & 109 & 55 & 7 \\
\hline$J A E$ & 2 & 105 & 53 & 42 \\
\hline$R F S$ & 1 & 49 & 49 & - \\
\hline$B S E$ & 1 & 42 & 42 & - \\
\hline$R F$ & 5 & 177 & 35 & 15 \\
\hline$J F S R$ & 3 & 97 & 32 & 16 \\
\hline$J B F A$ & 1 & 30 & 30 & - \\
\hline CGIR & 8 & 239 & 30 & 25 \\
\hline Others & 44 & 286 & 13 & 12 \\
\hline Total & 143 & 19,085 & 133 & 244 \\
\hline
\end{tabular}

Source: Authors' own elaboration

Executive compensation is a hot subject for researchers especially in the aftermath of 2007/2008 financial crises (OECD, 2015). Indeed, most of the literature regarding executive compensation in our sample was developed from 2011. Moreover, executive compensation has also become a topic of intense debate among principles setters (e.g., ӨCSE, 2015, 2017; BCBS, 2015; EBA, 2015), regulators (e.g., —2013), and media (e.g., Rajan, 2008; Rajan et al., 2008), with a particular focus c O compensation. 
Nonetheless, the evidence linking compensation practices to the effect on banks' risks and performance is mixed. There is a wide consensus in the literature regarding executive compensation that its level and composition may increase the risk-taking behaviour of bank managers $\longrightarrow$;on and James, 1995; Adams and Mehran, 2003; o, 2008; Bebchuk and Wei 1, 2010; $p$ and Kohler, 2010; $\rightarrow$ et al., 2010; $\checkmark$ e et al., 2011; $\square$ g et al., 2012; $>\mathrm{g}$ et al., 2013; $\square \mathrm{g} \sim$, 2013). This is the reason why principle sette regulators identi $\sim$ as a critical issue in banks' soundness and stability. Moreover, exeeutive eompensation has also beeome a topic of intense debate among principles setters (e.g., OCSE, 2015, 2017, BCDS, 2015, EBA, 2015), regulators (e.g., EP, 2013) and media (e.g., Rajan, 2008, Rajan et al., 2000, Kinkatuick, 2009), with a pantieular foetus on CEO compensation (Bai and Elyasiani, 2013; Chen et al., 2006; Fahtenbrach and Stulz, 2011; Thanassoutis et al., 2011; Hagendorff and Vallaseas, 2011, Fian and Yang, 2014). Referring in particular to financial institutions, BCBS asserts that remuneration structure is also linked to bank risk-taking behaviour ["Remuneration systems form a key component of the governance and incentive structure through which the board and senior management promote good performance, convey acceptable risk-taking behaviour and reinforce the bank's operating and risk culture" (BCBS, 2015)], furthermore it should be in line with the business and risk strategy, objectives.

A more detailed discussion of the findings is given by the following section, that reviews the most relevant articles related to bank corporate governance and specifically to board structure.

\section{Board structure}

The BoDs plays an important role in the governance arrangements of any firm (Fama and Jensen, 1983a, 1983b; Williamson, 1983). The main functions of the BoD are controlling and advising (Zahra and Pearce, 1989; Gabrielsson and Huse, 2004). The control function consists in the supervision of managers' activities so as to preserve shareholders' interests. As an advisor, the board supports strategic business decisions by providing opinions and directions to managers. As concerns financial institutions and in particular banks, the monitoring function is a crucial task for the board, due to the complexity and opaqueness of their business model (Levine, 2004; Mehran et al., 2011).

From an institutional perspective, improving board structure is considered vital by international standard setters in order to enhance corporate governance functioning (OECD, 2004, 2015; BCBS, 2006, 2010, 2015). Both the EBA and the BCBS consider $\mathrm{BoD}$ as one of the main internal governance features of banks. Directors are responsible for delegating power within the institution and setting objectives for the bank and the levels of risk-appetite. The $\mathrm{BoD}$ is also responsible for the organisation of the internal control system (EBA, 2011). BoDs has "overall responsibility for the bank, including approving and overseeing management's implementation of the bank's strategic objectives, governance framework and corporate culture" (BCBS, 2015). Moreover, "The board should structure itself in terms of leadership, size and the use of committees so as to effectively carry out its oversight role and other responsibilities. This includes ensuring that the board has the time and means to cover all necessary subjects in sufficient depth and have a robust discussion of issues" (BCBS, 2015). 
As mentioned in the introduction, contributions try to identify how board characteristics influence effectiveness and this mainly relate them to performance drivers and risk measures. Articles on board structure may be further subdivided in four different research sub-topics: board size, independence, diversity and CEO duality.

\subsection{Size}

Size is one of the characteristics that could be crucial in the effectiveness of BoD functioning (De Andres and Vallelado, 2008; Pathan, 2009; Grove et al., 2011; Adams and Mehran, 2011).

As above mentioned, boards' key roles are controlling and supporting firm's strategy. Indeed, corporate governance literature that examines the effect of board size (reviewed by Shleifer and Vishny, 1997; Denis and McConnell, 2003; Bebchuk and Weisbach, 2010) mainly outlined two alternative theories: the agency theory (Jensen and Meckling, 1976; Fama and Jensen, 1983a, 1983b; Jensen, 1993; Yermack, 1996; Eisenberg et al., 1998) which focuses on the relevance of board monitoring and argues that larger boards may reduce effectiveness and the resource-based view (Pfeffer, 1972; Pfeffer and Salancik, 2003; Hillman and Dalziel, 2003) that posits that larger boards may provide expertise and resources that are required to deal with complex activities and thus lead the board to be more effective in its advisory role.

Even though a great number of articles have investigated the impact of board size, evidence is inconclusive and confirms that in corporate governance of banks (as well as companies) one size does not fit all (Coles et al., 2008).

Figure 4 Board size and performance (see online version for colours)

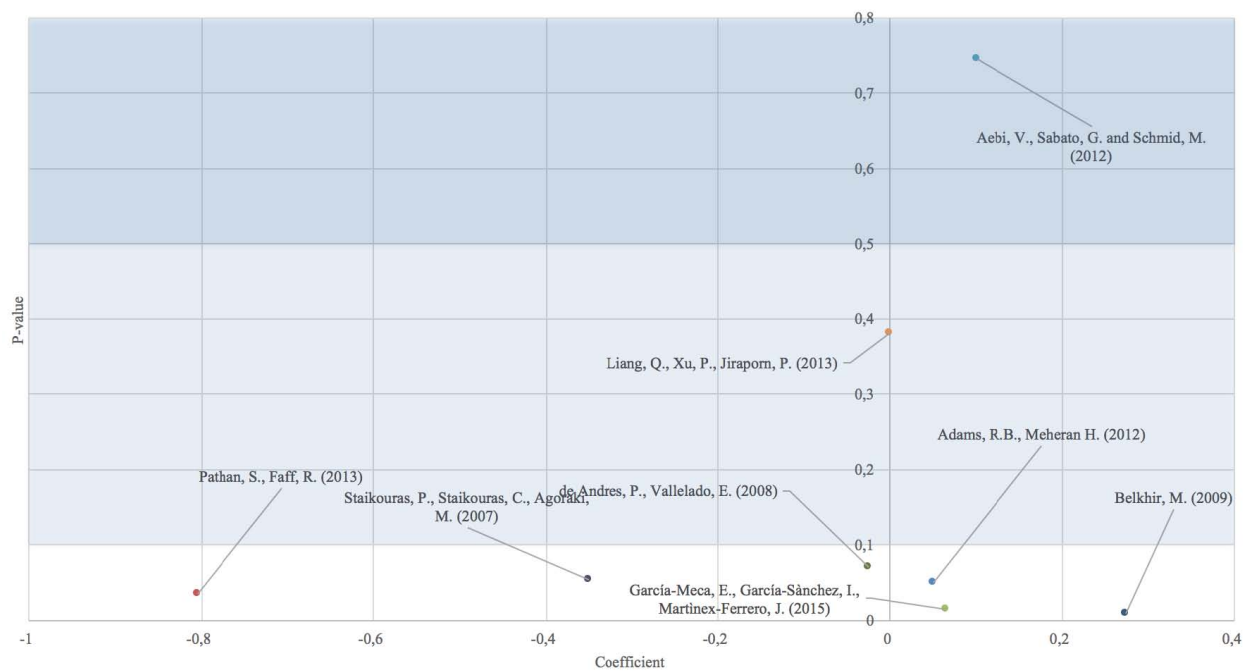

Source: Authors' own elaboration 
3 Board size and performance

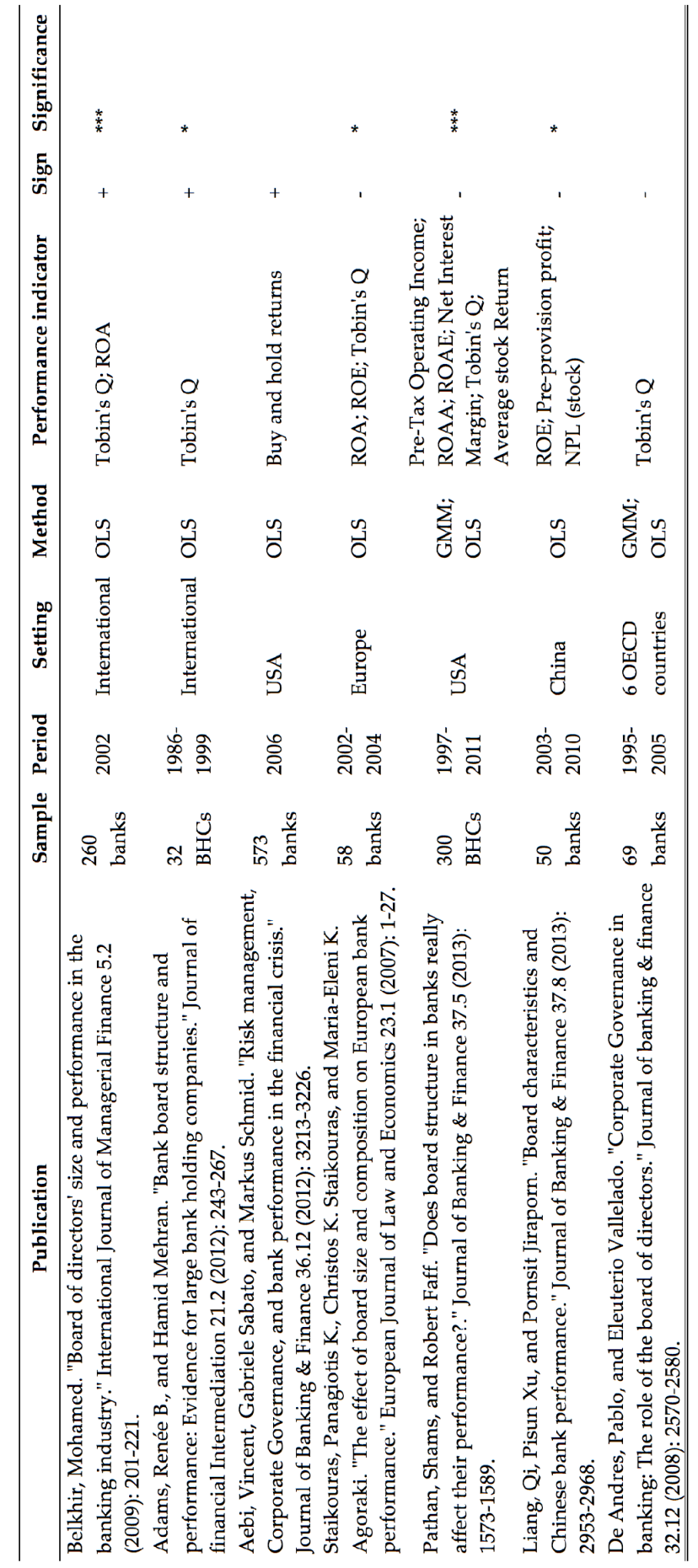


Adams and Mehran (2003, 2012) find support for the resource-based view and specifically that BHC boards are larger than those of manufacturing firms, although they have been declining in size over time (Adams and Mehran, 2003). Furthermore, the authors use a sample of 32 bank holding companies (BHCs) from 1986 to 1999 to investigate the relationship between the natural logarithm of board size and Tobin's Q. Their results suggest that larger boards enhance banks' performance and this result could be driven by a larger number of directors with subsidiary directorships within larger boards, that could contribute in dealing with organisational complexity (Adams

Mehran, 2003, 2012). Though it is not the main focus of their article, with Aebi

(2012) using data on 573 US banks over the crises period (1st July 2007 to 31 st December 2008) find that a larger board increases bank performance, measured by return on equity (ROE) and buy and hold returns, although board size is not the main focus of the article.

Consistent with this result (Belkhir, 2009), using panel data techniques with an ordinary least squares (OLS) estimation method, shows a positive relation between the logarithm of board size and two different measures of performance [Tobin's Q and return on assets (ROA)] on an international sample composed by 174 banks and savings and loan holding companies, over the 1995-2002 period. line and Safieddine (2011) run a fixed-effect model to examine the effect of board si d composition on performance using 749 Lebanese bank years' data during 1992-2006. The authors find that bank performance (measured by ROA and ROE) is positively related to board size.

Conversely and consistent with the agency theory, other studies support a negative association between board size and bank functioning, measured by both risk and performance.

Staikouras et al. (2007) find that large boards negatively influence bank profitability (measured by ROA, ROE and Tobin's Q) of a sample of 58 large European banks. Uwuigbe and Fakile (2011) use Nigerian Stock Exchange factbook data published in 2008, containing information on board size and performance proxies. The authors find that a smaller board size enhances financial performance and reduces free-riding problems in Nigerian banks.

Pathan and Faff (2013) conduct a two-step system generalised moments method (GMM) estimation method and an OLS regression of different performance measures (pre-tax operating income, average ROE, average ROA, net interest margin, Tobin's Q and average stock return) and find a significant and negative relationship with board size for a sample of 300 BHCs over the period 1997-2000. Wang et al. (2012) study the relationship between corporate governance and performance by using an innovative two-stage approach based on capital adequacy, asset quality, management earnings and liquidity (CAMEL) rating. The authors find that there are negative impacts of board size on US BHCs' performance in 2007.

Liang and Jiraporn (2013) analysing a sample of 50 largest Chinese banks during 2003-2010 find that board size has a significantly negative impact on bank performance and bank loans quality.

Lastly, there are numerous articles that do not find any statistically robust relationship between board size and bank functioning that led researchers to question to what extent board size matters for firm performance.

Simpson and Gleason (1999) find no effect of the number of directors on the probability of financial distress as well as Belkhir (2009), analysing 174 US financial 
companies. This is also consistent with results outlined by Brogi (2011) in comparing the influence that board size exerts respectively on 67 firms and 33 banks performance.

Finally, $\square$ ns et al. (2012) do not find that board size is related to bank performance ng the crisis. Conversely, De Andres and Vallelado (2008) analyse data of 69 banks from six OECD countries over the period 1995-2005. The authors obtain a hump-shaped relationship between board size and performance that suggests that the ideal number of bank directors to be around 19 .

Results extend $\square$ ker et al. (2007) and Grove et al. (2011) that find some evidence for an inverted U-s $d$ relationship between ROA and board size. Figure 4 and Table 3 summarise results from a sub-sample of articles that apply comparable methodologies.

Literature regarding the relationship between board size and risk is relatively more recent possibly fuelled by the financial crisis that evidenced the short-comings of ROE as a measure of performance in banking. Again, mixed results emerge.

Pathan (2009) and Minton et al. (2012) find that bank board size of US banks is negatively related to risk-taking (measured as total risk, idiosyncratic risk and systematic

during the pre-crisis period. This is also consistent with the study of Faleye and Inan (2010) that find that smaller boards ensure fewer junk loans provisioning of banks and are also reduce speculative actions on a sample of 51 banks over 1994-2006. Rachdi and Ben Ameur (2011) explore data of 11 large Tunisian commercial banks over the period 1997-2006 in order to investigate whether board characteristics affect performance and incentives to take risk in banking industry. Using both generalised least square (GLS), random effect (RE) and GMM system approaches, their results support the idea that bank board structure is a determinant factor for bank performance and bank risk-taking. In particular, the authors find a small bank board is associated with more performance (measured by ROA and ROE) and with more bank risk-taking (Z-score). $~ e r$ et al. (2012) argue that during the recent financial crisis board size, as well as $\mathrm{r}$ corporate governance characteristics of US commercial banks are not ed to bank stability (measured in terms of probability of default). Garcia-Marco and ez-Fernandez (2008) exploring a sample of Spanish banks, show that board size matters for risk-taking, and in particular they find smaller size institutions assuming lower risks, due to a moral hazard behaviour. More recently, $\square$ siani and Ling (2015) investigate the association between busy directors and both -2 performance and risk by employing the three stages least squares (3SLS) technique. Though their main focus is the impact of risk management characteristics on banks performance, the authors find that performance and board size do not have a significant relationship, whereas the number of directors is strongly and positively associated with higher risk-taking (total, market, idiosyncratic, credit and default risks).

From an institutional perspective, standard setters and regulators tend to focus respectively on what the board should and must do and therefore underline the importance of the competences of board members as opposed to the structural icteristics of the board (Bank of Italy, 2013; BCBS, 2010, 2015; Brogi, 2011; EBA,

). The analysis result in a there is a noteworthy lack of univocal consensus about an adequate board size in order to enhance performance and risk-avoiding. This is also notably from an institutional perspective. The $\mathrm{BoD}$ should "periodically, and at least annually, assess the structure, size, composition and performance of the management body and make recommendations to the management body with regard to any changes" (CRD IV). This is in line with the BCBS (2015) principles that suggest to BoD to 
"periodically review its structure, size and composition as well as committees' structures and coordination."

\subsection{Independence}

The BoD is the bridge between management and shareholders (OECD, 2004, 2015). Studies concerning board structure point out that the presence of independent directors (i.e., directors without direct ties with management) on the board contribute to a better monitoring of managers (Fama and Jensen, 1983a, 1983b; Boyd, 1994; Rechner and Dalton, 1991). This strand of literature also belongs to the agency theory and in particular it is related to the study of Jensen and Meckling (1976), Fama and Jensen (1983a, 1983b) and Beasley (1996). The latter argue that the agency problem deriving from the separation between ownership and control needs to be mitigated with a sound and efficient corporate governance. The agency relationship is the engagement of an agent (manager) to preserve and safeguard principal (shareholder's) interests on its behalf (Jensen and Meckling, 1976). Conventional wisdom recognises that independence, diversity and expertise enhance corporate governance quality and safeguard shareholders' interests. Alternative views also exist on the role of independent directors.

Fama and Jensen (1983a, 1983b) and Beasley (1996) identify independence as a vital characteristic of directors to mitigate agency conflicts between management and shareholders because their role in the board permit them to perform a better critical monitoring function. A different perspective is provided by the stewardship theory (Donaldson and Davis, 1991; Kent et al., 2010). Following this view, inside and executive directors have greater knowledge than independent directors with respect to their company's characteristics and provide better decision-making.

Bank corporate governance literature also recognises the level of independence of the BoDs as a critical issue for internal governance of banks. As well as corporates, banks BoDs should act in order to preserve shareholders' interest. Nonetheless, banks differ from other types of firms since they have a far wider number of stakeholders, that include depositors and other debt holders. Thus, the monitoring function of the BoD of banks is very important. Univocal consensus on the ideal level of independent members of the board is still missing, but most of the literature shows that a higher level of outsider representation increases the likelihood of the efficient outcome for the bank, measured by performance and risk-avoiding capabilities.

Figure 5 and Table 4 show the findings of a sub-sample of comparable (as concern the methodology) articles.

In line with agency theory, independent directors have incentives to properly exert the control function, because they seek to protect their reputation (Pathan, 2009). Li and Song (2013) find that board independence positively affects bank value of an international sample of banks. Consistent with this view, Pathan and Skuly (2010) also find an endogenous relationship between different bank corporate governance characteristics. Using a sample of 212 US BHCs duning the period 1997-2004, authors show that larger (in terms of assets) and more diversiffed banks have larger and more independent boards. In the same geographieal setting, Comett et al. (2010) extend the sample of observation to 300 publiely traded US banks during the financial erisis.

The authors find that bank performance is positively affected by a more independent board. Furthermore, De Andres and Vallelado (2008) show a nonlinear (hump 
shaped) relationship between board independence and performance, similar to the above-mentioned result regarding the relationship between board size and performance. Liang and Jiraporn (2013) investigate the relationship between the performance of 50 Chinese banks [measured by ROE, pre-provision profit and stock of non-performing loans (NPLs)] during 2003-2010 using an OLS methodology. The authors find that independence of BoDs positively affects bank performance. More recently, García-Meca et al. (2015), show that Tobin's Q and ROA are positively affected by the presence of a higher number of independent directors, although it is not the main aspect studied in the article. They examine the board structure of 159 banks in nine countries during 2004-2010 using a GMM methodology, focusing especially in the impact of gender diversity on bank performance, as further investigated in this paper.

Also in line with the agency theory and consistent with the positive results in terms of performance, there is some evidence of a negative relationship between board independence and bank risk-taking. Indeed, Pathan (2009) investigating a sample composed by 212 US BHCs over 1997-2004 as in Pathan and Skully (2010), with a GLS and a RE technique, find that board independence is strongly and negatively related to bank risk (measured by total risk, idiosyncratic risk, and systematic risk). Similar results are reported in Minton et al. (2012) and $\square$ e and Krishnan (2010). The latter find that board independence reduces riskines asured by the long-term $\mathrm{S} \& \mathrm{P}$ credit rating and inclusion of financial covenants in loan contracts, although it is not related to the lending risk diversification. Yeh et al. (2011) examine whether the performance during the recent financial crisis is better for financial institutions with more independent directors on different committees. Using the data of the 20 largest financial institutions from G8 countries during the 2007-2008 financial crisis the authors show that performance during the crisis is higher for financial institutions with more independent directors on auditing and risk committees. Moreover, the influence of committee independence on bank performance is particularly relevant for civil law countries (measured by a dummy variable). Yeh et al. (2011) also suggest that regulation authorities should enforce regulation compliance to improve director independence, particularly for auditing and risk committees in banking industry, since independent directors in banking are supposed to reduce excessive risk-taking behaviours.

Even if independent directors may enhance the effectiveness of monitoring bank management, they may lack in practical bank business expertise (Adams and Mehran, 2012). Thus, supporting the stewardship theory also in bank corporate governance, Adams and Ferreira (2007) comment the negative result obtained between performance and independence with the reduction of the information among boards, due to the outside position of independents. This condition negatively affects the advisory role of the board and may also reduce its monitoring function.

Belkhir (2009) relates different characteristics of bank corporate governance with Tobin's Q, and find that a higher number of independent directors negatively affects the

rmance of an international sample of 260 banks, using an OLS methodology. Aebi

(2012) also find a negative relationship between the percentage of independent directors and performance but their findings are not totally supported by the significance of their results. Consistent with this view is the above-mentioned study of Pathan and Faff (2013). The authors find a negative relationship between different performance measures and independence of the board.

As in the case of board size, some authors do not find robust correlations between director independence and bank results, both in terms of performance and risk-taking. 
As concerns performance, $\longrightarrow$ ns and Mehran (2005) and Staikouras et al. (2007) find no significant relation reen the degree of board independence (measured by the percentage of independent directors) and performance. The latter looking for the effect of board composition on the performance of 58 European banks, does not find a significant relation between independence and ROA.

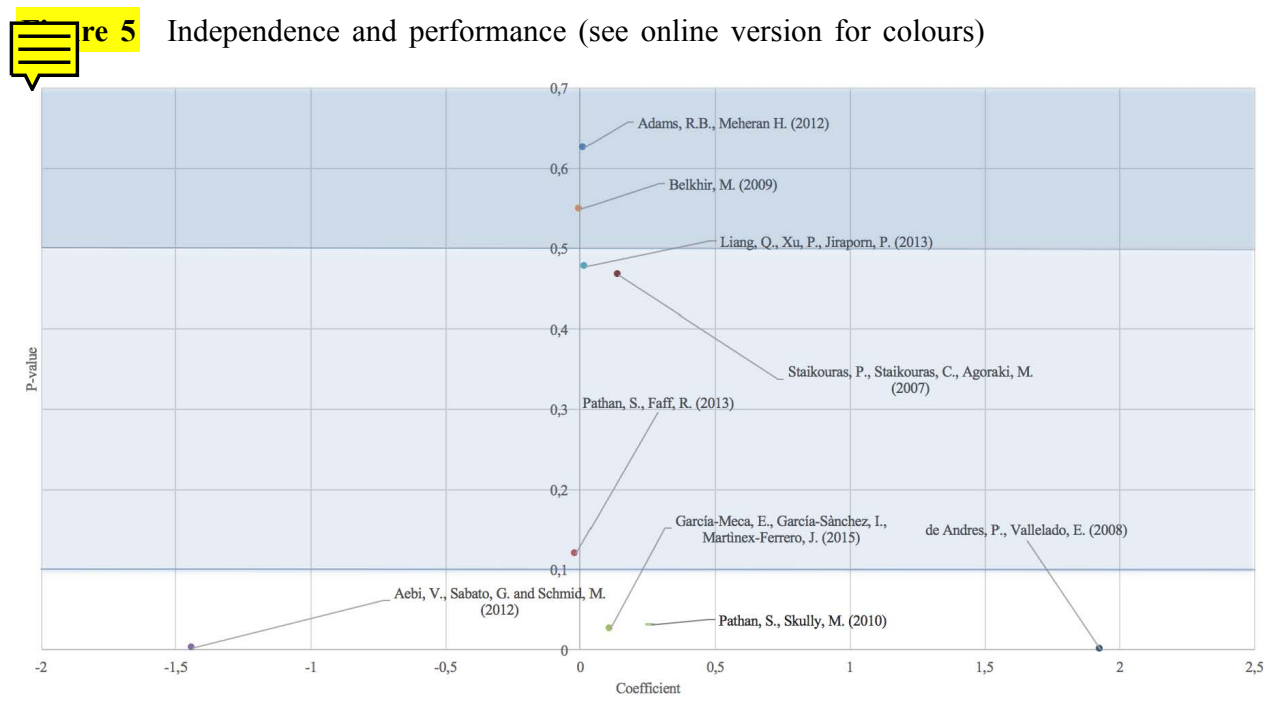

Source: Authors' own elaboration

Adams and Mehran (2012), using a sample of 32 international BHCs receiving bailout money during 1986-1999 does not find a negative relationship between Tobin's Q and independence analysed with an OLS estimation method. Moreover, the author suggests that independence may not always have the sufficient expertise to oversee complex banking firms.

Pi and Timme (1993), $\rightarrow$ ith et al. (2002) and Simpson and Gleason (1999), study the effect of a highe aber of independent directors on bank boards on the probability of financial distress. Nonetheless as mentioned above, there is a wider strand of literature supporting the relevance of board independence in the development of good corporate governance and a consequent enhancement of bank functioning (Peni and Vähämaa, 2012). Indeed, standard setters and regulators focus on board composition and favour independence. Hence, regulation and legal systems have a significant impact on internal governance arrangements of banks (Ferreira et al., 2012; Li and Song, 2013). In particular, Li and Song (2013) reach two main conclusions in their study: empowering official supervision reduces board independence and encouraging private monitoring increases board independence. These findings are consistent with Barth et al. (2004) and Beck et al. (2006).

Actually, since 2002 the Sarbanes-Oxley Act requires that boards have audit committees consisting only of independent outside directors. The codes of best practice for corporate governance issued in many countries have called for greater outside representation (Denis and McConnell, 2003). Despite the fact that national approaches on the definition of independence (IOSC, 2007; OECD, 2017). 
Table 4 Independence and performance

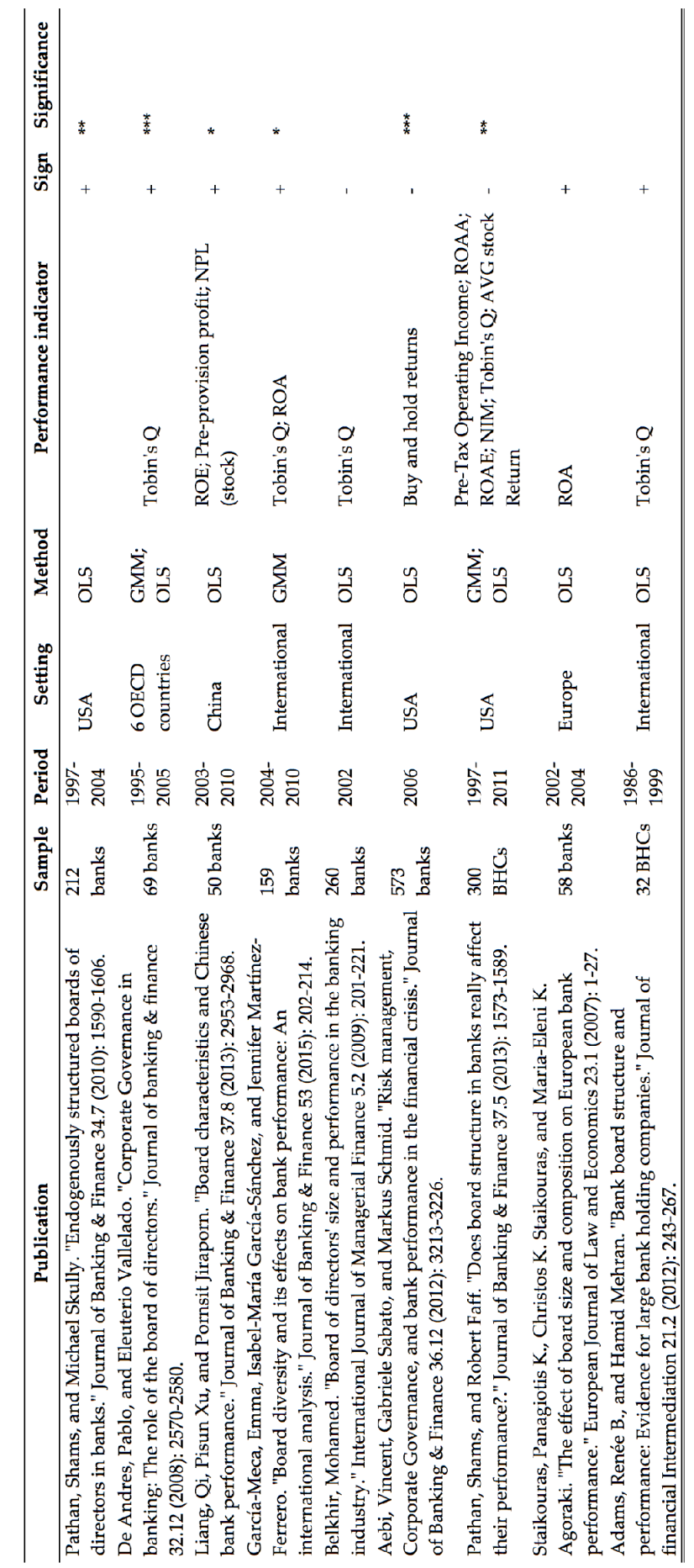

Source: Authors' own elaboration 


\subsection{CEO duality}

Another important issue in researches conducted on board structure of banks is the so-called CEO duality. It represents a situation in which the CEO of a bank is also chair of the BoDs.

Consistent with agency theory (Jensen and Meckling, 1976) CEO duality may reduce the ability of the board in preserving shareholders' interests. Indeed, CEO may not separate personal interest from shareholders' interests and the control function of the board may be less effective (Jensen, 1993; Lasfer, 2006). Moreover, the presence of a CEO who is also the Cahir of the board can mitigate the agency problem by moderating the effect of board involvement in executive management. From this perspective in the absence of CEO duality, the requirement of a minimum level of independent directors in order to enhance the advisory function of the board may be reduced without affecting the monitoring function. The stewardship theory states that CEO duality results in a more efficient and rapid decision-making process. Nonetheless it enhances the strategic vision of the board, by providing long-term objectives in line with shareholders' interests.

Focusing on financial institutions, CEOs are key decision makers. In particular, their risk propensity has a decisive role in the definition of the strategy of the bank (Adams and Ferreira, 2007). As a consequence, their position has a strong effect on both risk and performance of a bank. Indeed, empirical research on the impact of CEO duality on banks' performance (Pi and Timme, 1993; Johnson et al., 1996; ith et al., 2002;

er, 2009; in et al., 2011) and banks' risks (Simpson and Gl 1, 1999; Pathan, ; elb nd Nabila, 2011; onghe et al., 2012; Rachdi et al., 2013) provide differ unclusion on the impact $\mathrm{c}-\mathrm{O}$ duality, nonetheless most of the findings are not supported by sufficient significance. As concerns performance, Pi and Timme (1993) find that banks with CEOs who are also chairs of the board, over performed in respect of a situation without CEO duality. In particular, the authors study 112 US banks during 1987-1990 and show a positive relation between CEO duality and ROA and an inverse relation with costs.

Regarding the empirical evidences of CEO duality affecting risk-taking of banks, several authors find some evidence that CEO power is negative related with bank risk-taking. In particular, Simpson and Gleason (1999) find a lower probability of financial distress when there is CEO duality using a sample of 287 banks over the period 1989-1993. They also suggest that the risk-avoiding function of a CEO who is also the Chair of the board is given by the bias of protecting his role in the board. Consistently, Pathan (2009) and elbene and Nabila (2011) investigate the relationship of different corporate governa rariables of two different samples of banks and find the presence of a CEO who is also the chair of the board is inversely related with bank risks. The first author uses a sample composed by 212 US BHCs during 1997-2004 and regresses CEO duality on different risk measures as total risk, idiosyncratic risk, systematic risk, assets return risk and insolvency risk). $\square$ elbene and Nabila (2011) use a static panel and GLS methodology on a sample of $\mathrm{t}$ mmercial banks listed on the Tunisian Stock Exchange during 1995-2007 measuring risk with three different drivers: total risk, insolvency risk, and beta. The authors find that the coefficient of CEO duality is positive and statistically significant and positively associated with total risk and insolvency risk probably. This result is driven by a reduction of the control effectiveness of the governance structure, resulting in an increase in bank risk-taking. Rachdi et al. (2013) try to assess whether bank board structure is associated with risk. The authors 
use a sample of 11 Tunisian conventional banks over the period 2001-2011 and find that duality on boards is associated with more insolvency risk, but has no significant effect on insolvency and credit risk. onghe et al. (2012) use a stochastic frontier approach on 65 commercial banks op $\mathrm{g}$ in Turkey between 1988 and 2009. The authors, looking for a relationship between both internal and external governance mechanisms (respectively CEO duality, board experience, political connections, education profile and discipline exerted by shareholders, depositors, or skilled employees) and bank performance, find that the presence of a more experienced CEO (controlled by the cumulative number of years a particular manager has been at the top of his or her organisation) generally increases risk/return efficiency, as suggested by human-capital theory (Becker, 1962). $\square$ nak and Bektas (2008) also observe Turkish commercial banks (27) operating i market between 2001-2004, but their findings support the stewardship view, by showing how the presence of duality increases the risk of principal-principal conflict. The authors run a cross-sectional data analysis investigating the association of different governance drivers (board independence, CEO duality, board size, and board tenure) with bank performance measured by ROA.

- Inother evidence of the consistency of the stewardship view is given by Larcker (2007). The latter is one of the first papers that finds CEO duality negatively impacting on performance. The authors investigate different corporate governance variables of a sample of 2106 financial and non-financial firms between 2002 and 2003 by using a principal component analysis (PCA). This method is used to develop 14 multi-indicator indices from 39 individual governance indicators, including CEO duality. Wang et al. (2012) also report a negative impact of CEO duality on efficiency by exploring the relationship between the operating performance and corporate governance of 68 BHCs in the US with a modified data envelopment analysis (DEA) method.

Figure 6 CEO duality and performance (see online version for colours)

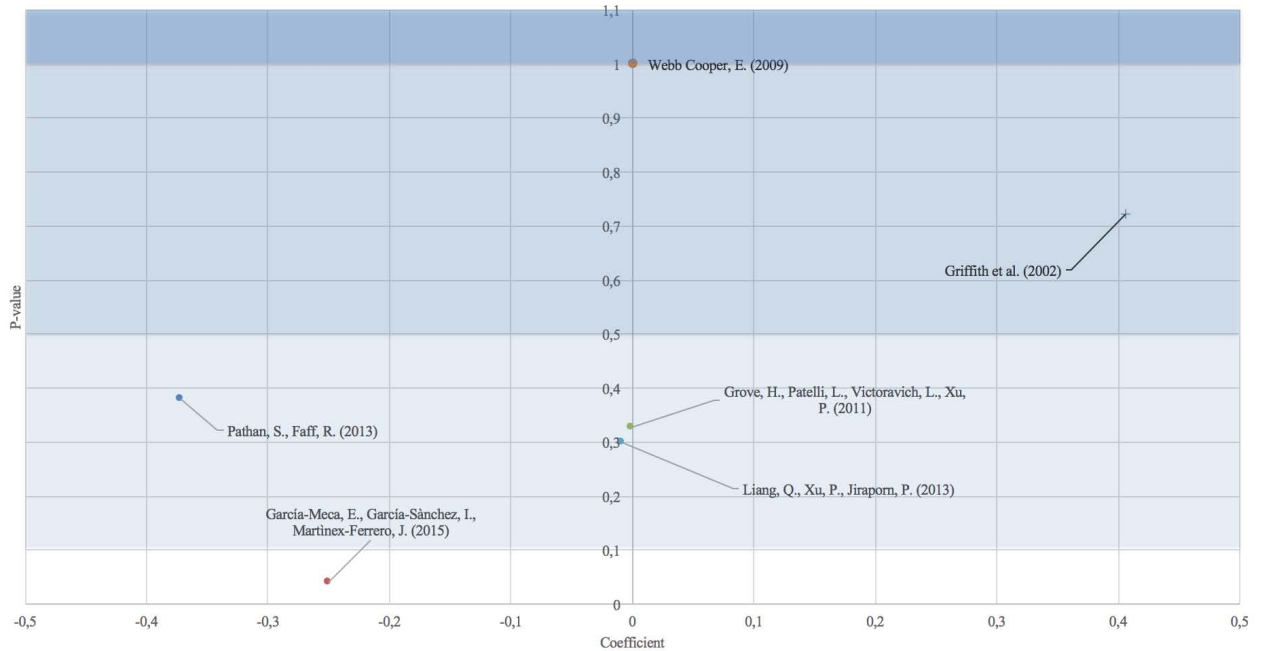

Source: Authors' own elaboration 
Table 5 CEO duality and performance

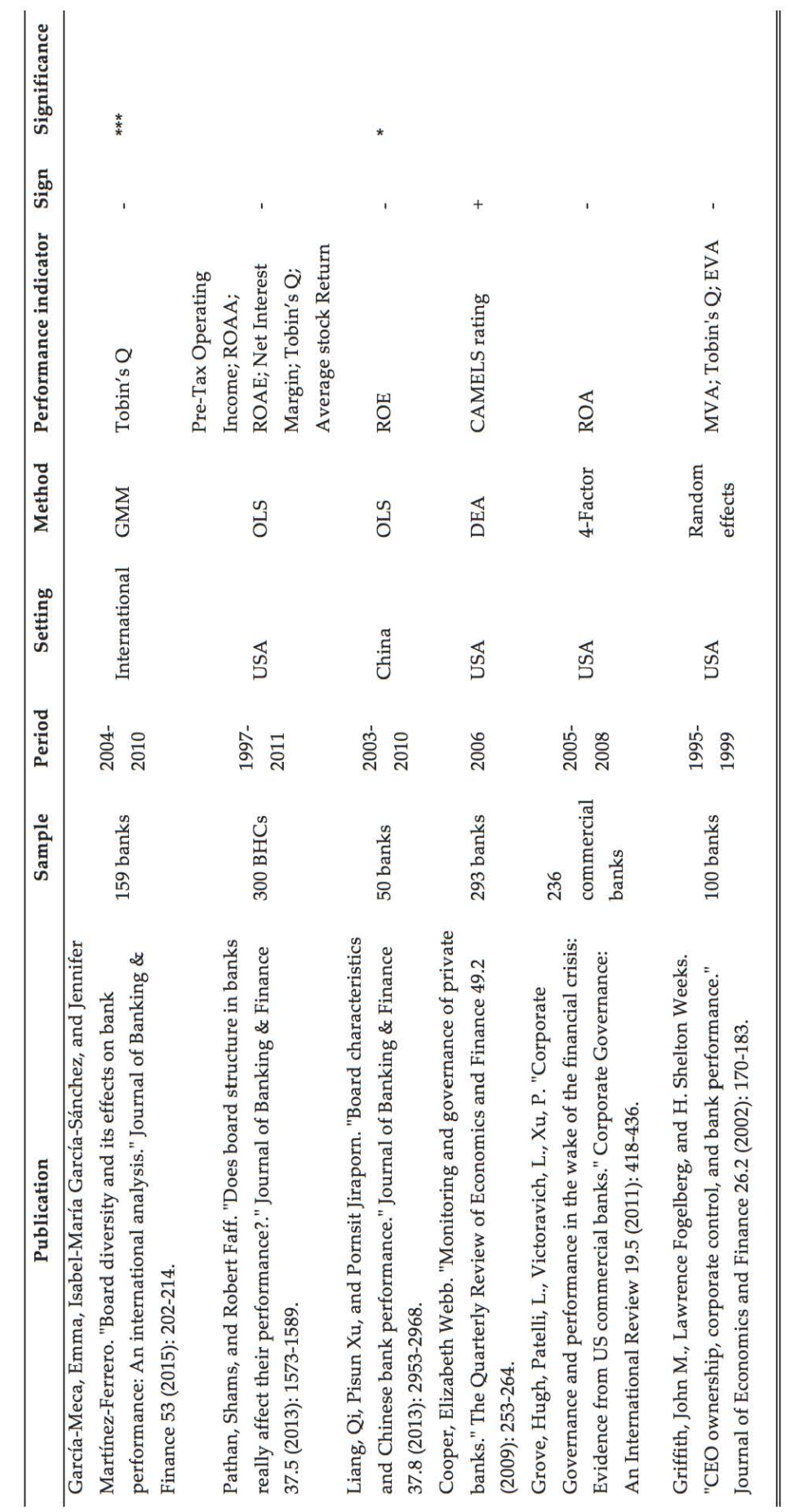

Source: Authors' own elaboration 
Researchers also investigate whether CEO duality is not only associated with bank 7 performance measures but also with bank functioning. Indeed, Faleye and Krishnan

0) and Grove et al. (2011) study the relationship between CEO duality and lending activity. In particular, $r$ e and Krishnan (2010) find that the probability of lending to high-risk borrowers eases with CEO duality. Grove et al. (2011) find a negative relationship with bank performance but do not find a significant association with loan quality, by adopting the factor structure to measure multiple dimensions of corporate governance for 236 US public commercial banks. Semenova and Savchenko (2015), exploring the effect of combining positions between the BoDs and top management, demonstrate that there is a need for a broader approach to regulating the spheres of director responsibility, and avoid CEO duality for developed countries. They obtain this result from a sample of banks in 112 countries and measure bank profitability, both in terms of profitability for managers (ROA) and return for shareholders (ROE). However, their conclusions seem to be true only for developed economies.

on et al. (1996) conducted a meta-analysis investigate whether a situation of duality board is related to performance, and their result reveal suggest no relationship of a meaningful level. The latter finding is consistent with the results of other later banking studies that reveal not significant relationship among variables ith et al., 2002; Cooper, 2009; Adnan et al., 2011; $\square$ et al., 2012; Berger 2014). In particular, Griffith et al. (2002) assert that uation in which CEO is also the chair of the $\mathrm{BoD}$, has no significant impact on performance because adding responsibilities do not result in an improving in CEOs capacity to affect performance. Cooper (2009) finds insignificant relationship between the CEO duality and bank performance (measured by Tobin's Q), economic value added (EVA) and market value added (MVA). Furthermore, Adnan et al. (2011) show a negative but insignificant relationship between CEO duality and bank performance. At last, $\square$ et al. (2012) do not find that CEO duality affects buy-and-hold returns of US ba included in their sample. Berger et al. (2012) find no effect of CEO duality on bank default probabilities by investigating a sample of 249 bank failures and 4,021 non-default US commercial banks over the financial crisis period (2007-2010). Figure 6 and Table 5 summarise findings of a sub-sample of comparable (as concern the methodology) articles. As reported in the latter, the academic point of view is mainly directed to define CEO duality as a situation to be avoided by the BoD.

Institutional perspective regarding the CEO duality is largely in line with academic point of view. Indeed, the combination of the role of board chair and CEO is possible among many of the jurisdictions with one-tier board systems. As a matter of fact, National competent authorities have duties and responsibility in determining whether or not a situation of CEO duality can be specifically identified as banks' value creator. Nonetheless, there is still a lot of work to do to by regulators and authorities clarify the issue CEO duality in banks.

\subsection{Diversity}

A widely researched question in corporate governance literature is whether diversity among board members affects firm performance.

Diversity on boards should improve independence, preserve minorities' rights, and offer different point of views in boards' meeting. Nonetheless, it may slow down board functioning and decision provisioning (Carter et al., 2003, 2010). Hence, literature 
concerning this topic is not univocal. Moreover, it recognises that also the type of diversity seems to be crucial (García-Meca et al., 2015). In particular, most of the studies focus on gender diversity and investigate whether a higher number of women directors can lead to better upshots in terms of effectiveness and performance. From an agency theory perspective, a higher number of women on the board improves independence and board monitoring function (Carter et al., 2003; Terjesen et al., 2009).

An extensive review of diversity on corporates' board is provided by Nielsen and Huse (2010), contrariwise, banking literature concerning diversity is limited and more recent. The only studies that investigate different types of diversity in banks' board are ndorff et al. (2010) and García-Meca et al. (2015). In particular, Hagendorff et al.

0 ) find that diversity (and independence) matter only under strict banking regulation regimes. In particular, the authors find that age, occupational and expertise diversity improve acquisition performance. Contrariwise, in less strict regulatory environments, corporate governance is virtually irrelevant in improving the performance outcomes of merger activities. García-Meca et al. (2015) analyse the relationship between board diversity (interpreted as gender and as nationality) and performance on a cross-country sample composed by 159 banks observing the period 2004-2010. They find opposing results due to the type of diversity: gender diversity increases bank performance; national diversity constrains it. At last, they also assert that within weaker regulatory and lower investor protection environments board diversity has less influence on banks' performance. The effects of gender diversity on banks performance are also investigated by a few other researchers (Pathan and Faff, 2013; Strøm et al., 2014; Nguyen et al., 2015) obtaining mixed results.

In particular, Pathan and Faff (2013) run a GMM estimation methods over a sample composed by 212 US BHCs and find that gender diversity has a positive effect on bank performance in the pre-Sarbanes-Oxley Act (SOX) period (1997-2002), but this relationship is becoming weaker in both the post-SOX (2003-2006) and the crisis periods (2007-2011). They also argue that this finding may be resulted by the consequential possibility of a reduction of more capable male directors on board. This is consistent with Nguyen et al. (2015). The latters analyse the issue of gender diversity in 308 US banks from January 1999 to December 2011 by investigate the impact on market performance and controlling for executives' appointments announcements. As in Pathan and Faff (2013), the authors find that gender diversity is not linked to measurable value effects.

Contrariwise, Strøm et al. (2014) find that a female CEO and a female chair of the board are positively related to performance of a cross-country panel of 329 microfinance institutions in 73 countries during 1998-2008.

As resulted by the survey conducted in this paper, gender diversity is also being investigated to explore its effects on bank risk-taking $\square$ abo and Gimeno, 2012; Berger et al., 2014) and functioning (Muller-Kahle and ellyn, 2011; Beck et al., 2013; rabarty and Bass, 2014).

Dc _.no and Gimeno (2012) investigate whether gender diversity impact on bank risk-taking of a sample composed by 612 European banks. In particular, the authors show three main findings:

1 a higher number of women directors reduces bank risk-taking

2 board size and woman directors number are positively related 
3 banks with growth objectives are more prone to include women on their board.

Berger et al. (2014) use a difference-in-difference estimation method to explore the relationship between different corporate governance characteristics (age, gender, and educational composition) and bank risk-taking, measured by the risk weighted assets density (RWA/total assets). Their findings show that a higher representation of women on boards improves bank risk-avoiding, although results are not strongly significant. Furthermore, they argue that the latter result can be explained by a women risk aversion hypothesis.

Muller-Kahle and Lewellyn (2011) try to asses a relationship between board composition and subprime lending, by investigating also gender diversity issues on a sample of 74 US banks during the period 1997-2005. For what concerns gender diversity, their results show that subprime lenders have boards presenting a lower percentage of women directors. Beck et al. (2013) explore a similar research question but focus to loan officers rather than bank executives. The authors use data of a commercial bank in Albania and find a lower likelihood to turn problematic of loans originated by female loan officers than loans originated by male loan officers. Thus, loans screened and monitored by female loan officers present lower default rates. The authors confer this result to a better capacity of women to build relationship with borrowers better than male officers. At last, Chakrabarty and Bass (2014) investigate data of 280 international microfinance institutions, to asses whether a higher presence of women on boards may reduce banks' operating costs. Their results confirm the hypothesis of a positive effect of women on boards and lead the authors to argue that microfinance institutions with high operating costs may benefit from appointing a board with socio-economic expertise and women directors.

Standard setters started to promote diversity on board in the last decade. In 2011 the OECD announced its Gender Initiative which suggests "The need to introduce quotas for women in boardrooms or in senior management is being widely debated and, conditional on data availability, deserves further analysis to understand its benefits in terms of women's employment outcomes and firm performance." For what concerns banks board composition, the BCBS (2015) provides specific suggestions regarding diversity, that are outlined in principle 2: "The board should be comprised of individuals with a balance of skills, diversity and expertise, who collectively possess the necessary qualifications commensurate with the size, complexity and risk profile of the bank."

Indeed, concerning financial institutions, in 2011, the Committee on Economic and Monetary Affairs provided a report on the corporate governance of financial institutions to suggest to EC an increase of female representation on financial institutions' boards by arguing that "greater diversity would tend to reduce the sector's vulnerability to crises, contribute to stability, and improve the quality of debate and decision making."

As a result, the view point of a need to improve and preserve diversity on boards is shared by both standard setters and regulators and is also in line with most of the papers surveyed in this research. However, even thought academics focus on diversity of corporates' boards since the last decade of the twentieth century (Nielsen and Huse, 2010) forestalling both standard setters and regulators, for what concerns financial institutions, the development of suggestions and guidance is receiving growing attention of standard setters and regulators along with academics findings. 


\section{Conclusions}

Despite the considerable and increasing effort in exploring the effects of bank corporate governance practices, the relationship between bank board characteristics and both performance and risk-taking remain elusive. We perform a systematic literature review on the characteristics of bank boards of directors with the aim of summarising the main findings of previous researchers. We contribute to the literature by identifying areas of improvement in the bank corporate governance literature. Indeed, our analysis shows that though there is an increasing understanding of the fundamentals of bank corporate governance, and in particular of the characteristics of banks' BoDs, research has not yet found the magic formula for board composition as results are at best ambiguous and sometimes even contradictory. This could stem from the fact that research tends to investigate boards from the outside considering composition and at best professional characteristics of board members. Due to the difficulties in obtaining data, there is a notable lack of studies on board dynamics and effectiveness from the inside. Despite the inconclusive evidence, regulators and supervisors focus on the characteristics of banks' BoDs. This means that there is still a lot of work to do to identify the practices that improve bank performance and effectively manage risk. Moreover, research adopting a more holistic approach capable of capturing the multifaceted complexity of corporate governance and encompassing the other areas of bank corporate governance (such as risk management, remuneration and ownership structure) could be possibly be more successful in providing guidance.

\section{References}

Abatecola, G., Mandarelli, G. and Poggesi, S. (2013) 'The personality factor: how top management teams make decisions. A literature review', Journal of Management \& Governance, Vol. 17, No. 4, pp.1073-1100.

ya, V.V., Saunders, A. and Hasan, I. (2002) 'Should banks be diversified? Evidence from ndividual bank loan portfolios', Journal of Business, Vol. 79, pp.1355-1412.

Adams, R.B. and Ferreira, D. (2007) 'A theory of friendly boards', The Journal of Finance, Vol. 62, No. 1, pp.217-250.

Adams, R.B. and Mehran, H. (2003) 'Is eorporate governanee different for bank holding eompanies?', Economic Poticy Review, pp. $123-142$.

Adams, R.B. and Mehran, H. (2011) 'Corporate performance, board structure, and their determinants in the banking industry', FRB of New York Staff Report, No. 330.

Adams, R.B. and Mehran, H. (2012) 'Bank board structure and performance: evidence for large bank holding companies', Journal of Financial Intermediation, Vol 21, No. 2, pp.243-267.

Allen, F. and Santomero, A.M. (2001) 'What do financial intermediaries do?', Journal of Banking \& Finance, Vol. 25, No. 2, pp.271-294.

Bank of Italy (2013) Circular, No. 285, 17 December.

Barth, J.R., Caprio, G. and Levine, R. (2004) 'Bank regulation and supervision: what works best?', Journal of Financial Intermediation, Vol. 13, No. 2, pp.205-248.

Committee on Banking Supervision (BCBS) (2004) Corporate Governance Principles for Banks, Juidelines, July.

Basel Committee on Banking Supervision (BCBS) (2006) Corporate Governance Principles for Banks, Guidelines, July. 
Basel Committee on Banking Supervision (BCBS) (2010) Corporate Governance Principles for Banks, Guidelines, July.

Basel Committee on Banking Supervision (BCBS) (2015) Corporate Governance Principles for Banks, Guidelines, July.

Berger, A.N., Kick, T. and Schaeck, K. (2014) 'Executive board composition and bank risk taking', Journal of Corporate Finance, $: 8$, pp.48-65.

Bhattacharya, S. and Thakor, A.V. 3) 'Contemporary banking theory', Journal of Financial Intermediation, Vol. 3, No. 1, pp.2-50.

Becht, M., Bolton, P. and Röell, A. (2011) 'Why bank governance is different', Oxford Review of Economic Policy, Vol. 27, No. 3, pp.437-463.

Bebchuk, L.A. and Weisbach, M.S. (2010) 'The state of corporate governance research', Review of Financial Studies, Vol. 23, No. 3, pp.939-961.

1uk, L.A. and Fried, J.M. (2010) 'How to tie equity compensation to long-term results', Journal of Applied Corporate Finance, Vol. 22, No. 1, pp.99-106.

Beasley, M.S. (1996) 'An empirical analysis of the relation between the board of director composition and financial statement fraud', Accounting Review, $3-465$.

Beck, T., Levine, R. and Loayza, N. (2000) 'Finance and $>$ ources of growth', Journal of Financial Economics, Vol. 58, No. 1, pp.261-300.

T. and Demirguc-Kunt, A. (2006) 'Small and medium-size enterprises: access to finance as a growth constraint', Journal of Banking \& Finance, Vol. 30, No. 11, pp.2931-2943.

Belkhir, M. (2009) 'Board structure, ownership structure and firm performance: evidence from banking', Applied Financial Economics, Vol. 19, No. 19, pp.1581-1593.

Beltratti, A. and Stulz, R.M. (2009) 'Why did some banks perform better during the credit crisis? A cross-country study of the impact of governance and regulation', National Bureau of Economic Research, No. w15180.

A. and Means, G. (1932) Private Property and the Modern Corporation, Mac-Millan, New York.

Boaz, A. and Ashby, D. (2003) Fit for Purpose? Assessing Research Quality for Evidence based Policy and Practice, ESRC UK Centre for Evidence Based Policy and Practice, London.

Bos, W. and Tarnai, C. (1999) 'Content analysis in empirical social research', International Journal of Educational Research, Vol. 31, No. 8, pp.659-671.

Boyd, B.K. (1994) 'Board control and CEO compensation', Strategic Management Journal, Vol. 15, No. 5, pp.335-344.

Boyd, J.H. and De Nicolo, G. (2005) 'The theory of bank risk taking and competition revisited', The Journal of Finance, Vol. 60, No. 3, pp.1329-1343.

Brogi, M. (2008) Corporate Governance e sistema dualistico per banche e assicurazioni, Bancaria.

Brogi, M. (2011) 'Board, governance and firm performance: are financial intermediaries different?', Corporate Ownership \& Control, Vol. 39, No. 335, p.60.

Capio, G. and Levine, R. (2002) 'Comporate governanee in finance. concepts and international observations, Financial Sector Governance. The Rotes of the Public \& Private Sectors, Pp.17-50.

Caprio, G., Laeven, L. and Levine, R. (2007) 'Governance and bank valuation', Journal of Financial Intermediation, Vol. 16, No. 4, pp.584-617.

Carter, D.A., Simkins, B.J. and Simpson, W.G. (2003) 'Corporate Governance, board diversity, and firm value', Financial Review, Vol. 38, No. 1, pp.33-53.

Caselli, S. (2010) 'Governance and strategy within the financial system: tradition and innovation', Journal of Management \& Governance, Vol. 14, No. 3, pp.241-271.

Claessens, S. and Laeven, L. (2003) 'Financial development, property rights, and growth', The Journal of Finance, Vol. 58, No. 6, pp.2401-2436. 
Coff, R.W. (1999) 'When competitive advantage doesn't lead to performance: the resource-based view and stakeholder bargaining power', Organization Science, Vol. 10, No. 2, pp.119-133.

Coles, J.L., Daniel, N.D. and Naveen, L. (2008) 'Boards: does one size fit all?', Journal of Financial Economics, Vol. 87, No. 2, pp.329-356.

s, L. (2011) 'Women on boards. European Commission's network to promote women in Jecision-making in politics and the economy', The Quota-Instrument: Different Approaches Across Europe.

Davis, J.H., Schoorman, F.D. and Donaldson, L. (1997) 'Toward a stewardship theory of management', Academy of management review, Vol. 22, No. 1, pp.20-47.

De Andres, P. and Vallelado, E. (2008) 'Corporate governance in banking: the role of the board of directors', Journal of Banking \& Finance, Vol. 32, No. 12, pp.2570-2580.

Denis, D.K. and McConnell, J.J. (2003) 'International corporate governance', Journal of Financial \& Quantitative Analysis, Vol. 38, No. 1, pp.1-36.

Dika, I. et al. (2013) 'Corporate governance in banking system', Research Journal of Finance and Accounting, Vol. 4, No. 16, pp.18-22.

Donaldson, L. and Davis, J.H. (1990) CEO Governance and Shareholder Returns: Agency Theory or Stewardship Theory, Australian Graduate School of Management, University of New South Wales.

Donaldson, L. and Davis, J.H. (1991) 'Stewardship theory or agency theory: CEO governance and shareholder returns', Australian Journal of Management, Vol. 16, No. 1, pp.49-64.

Draghi, M. (2008) The Governor's Concluding Remarks for 2007, 31 May.

Eisenberg, T., Sundgren, S. and Wells, M.T. (1998) 'Larger board size and decreasing firm value in small firms', Journal of Financial Economics, Vol. 48, No. 1, pp.35-54.

Eisenhardt, K.M. (1989) 'Agency theory: an assessment and review', Academy of Management Review, Vol. 14, No. 1, pp.57-74.

Ellis, L., Haldane, A. and Moshirian, F. (2014) 'Systemic risk, governance and global financial stability', Journal of Banking \& Finance, $15, \mathrm{pp} .175-181$.

European Banking Authority (EBA) (2011) EB. delines on Internal Governance (GL 44).

ean Union (EU) (2005) Commission Recommendation on the Role of Non-Executive or supervisory Directors of Listed Companies and on the Committees of the (Supervisory) Board, 15 February.

ean Union (EU) (2013a) Directive 2013/36/Eu of the European Parliament and of the Council on Access to the Activity of Credit Institutions and the Prudential Supervision of Credit Institutions and Investment Firms, Amending Directive 2002/87/EC and Repealing Directives 2006/48/EC and 2006/49/EC, 26 June.

ean Union (EU) (2013b) Regulation (EU) No. 575/2013 of the European Parliament and of the Council on Prudential Requirements for Credit Institutions and Investment Firms and Amending Regulation (EU) No. 648/2012, 26 June.

ean Parliament (2011a) Resolution of 6 July 2011 on Women and Business Leadership. ean Parliament (2011b) Committee on Economic and Monetary Affairs, Rapporteur Ashley Fox Report on Corporate Governance in Financial Institutions, A7-0074/2011. ean Parliament (2012) Gender Quotas in Management Boards.

E.F. and Jensen, M.C. (1983a) 'Agency problems and residual claims', Journal of Law \& Economics, $7-349$.

Fama, E.F. and A, M.C. (1983b) 'Separation of ownership and control', Journal of Law \& Economics, $1-325$.

Ferreira, D., Ker D., Kirchmaier, T. and Schuster, E-P. (2012) Shareholder Empowerment and Bank Bailouts, London School of Economics Financial Markets Group Discussion Paper No. 714. 
Franks, J. and Mayer, C. (2001) 'Ownership and control of German corporations', Review of Financial Studies, Vol. 14, No. 4, pp.943-977.

Freeman, R.E. (1984) 'Strategic management: a stakeholder approach', Advances in Strategic Management, Vol. 1, No. 1, pp.31-60.

Financial Stability Board (FSB) (2013) Thematic Review on Risk Governance, Peer Review Report, 12 February.

Gabrielsson, J. and Huse, M. (2004) 'Context, behavior, and evolution: challenges in research on boards and governance', International Studies of Management \& Organization, Vol. 34, No. 2, pp.11-36.

García-Meca, E., García-Sánchez, I-M. and Martínez-Ferrero, J. (2015) 'Board diversity and its $\checkmark \mathrm{s}$ on bank performance: an international analysis', Journal of Banking \& Finance, Vol. 53, $2-214$.

man, C.A. and Rhoades, S.A. (1980) 'Owner vs. manager control effects on bank performance', The Review of Economics \& Statistics, pp.263-270.

Grove, H. et al. (2011) 'Corporate governance and performance in the wake of the financial crisis: evidence from US commercial banks', Corporate Governance: An International Review, Vol. 19, No. 5, pp.418-436.

Guthrie, J. et al. (2004) 'Using content analysis as a research method to inquire into intellectual capital reporting', Journal of Intellectual Capital, Vol. 5, No. 2, pp.282-293. eshoff, U. and Uhde, A. (2008) 'Consolidation in banking and financial stability in Europe', Iournal of Banking \& Finance, Vol. 33, No. 7, pp.1299-1311.

Hillman, A.J. and Dalziel, T. (2003) 'Boards of directors and firm performance: integrating agency and resource dependence perspectives', Academy of Management Review, Vol. 28, No. 3, pp.383-396. strom, B. (1979) 'Moral hazard and observability', The Bell Journal of Economics, pp.74-91.

K.J. (2013) 'Corporate governance of banks and other financial institutions after the financial crisis', Journal of Corporate Law Studies, Vol. 13, No. 2, pp.219-253.

Insch, G.S., Moore, J.E. and Murphy, L.D. (1997) 'Content analysis in leadership research: examples, procedures, and suggestions for future use', The Leadership Quarterly, Vol. 8, No. 1, pp.1-25.

International Organization of Securities Commissions (IOSC) (2007) Board Independence of Listed Companies Final Report.

Jensen, M.C. (1993) 'The modern industrial revolution, exit, and the failure of internal control systems', The Journal of Finance, Vol. 48, No. 3, pp.831-880.

Jensen, M.C. and Meckling, W.H. (1976) 'Theory of the firm: managerial behavior, agency costs and ownership structure', Journal of Financial Economics, Vol. 3, No. 4, pp.305-360.

Kent, P., Routledge, J. and Stewart, J. (2010) 'Innate and discretionary accruals quality and corporate governance', Accounting \& Finance, Vol 50, No. 1, pp.171-195.

Kirkpatrick, G. (2009) 'Corporate governance and the financial crisis', Financiial Market Trends, Vol. 96, No. 1, pp.1-30, OECD.

Kyereboah-Coleman, A. and Biekpe, N. (2006) 'Do boards and CEOs matter for bank performance? A comparative analysis of banks in Ghana', Journal of Corporate Ownership \& Control, Vol. 4, No. 1, pp.119-126.

Lasfer, M.A. (2006) 'The interrelationship between managerial ownership and board structure', Journal of Business Finance \& Accounting, Vol. 33, Nos. 7-8, pp.1006-1033.

Levine, R., Loayza, N. and Beck, T. (200) 'Financial intermediation and growth: causality and causes', Journal of Monetary Economics, Vol. 46, No. 1, pp.31-77.

Levine, R. (2004) The Corporate Governance of Banks: A Concise Discussion of Concepts and Evidence, Vol. 3404, Bank Publications.

Levine, R. and Zervos, S. 'Stock markets, banks, and economic growth', American Economic Review, $7-558$. 
ellyn, K.B. and Muller-Kahle, M.I. (2012) 'CEO power and risk taking: evidence from the ;ubprime lending industry', Corporate Governance: An International Review, Vol. 20, No. 3, pp.289-307.

Li, L. and Song, F.M. (2013) 'Do bank regulations affect board independence? A cross-country analysis', Journal of Banking \& Finance, Vol. 37, No. 8, pp.2714-2732.

Liang, Q., Xu, P. and Jiraporn, P. (2013) 'Board characteristics and Chinese bank performance', Journal of Banking \& Finance, Vol. 37, No. 8, pp.2953-2968.

, G., Markarian, G. and Milne, A. (2011) 'Bankers' compensation and fair value accounting', Iournal of Corporate Finance, Vol. 17, No. 4, pp.1096-1115.

Llewellyn, D.T. (2002) 'Alternative approaches to regulation and corporate governance in financial firms', Financial Risks, Stability, \& Globalization, pp.117-163.

Macey, J.R. and O’Hara, M. (2003) 'The corporate governance of banks', Economic Policy Review, ', No. 1.

Mah J.T. and Pandian, J.R. (1992) 'The resource-based view within the conversation of strategic management', Strategic Management Journal, Vol. 13, No. 5, pp.363-380.

innell, P. (2012) 'The governance of strategic risks in systemically important banks', Journal of Risk Management in Financial Institutions, Vol. 5, No. 2, pp.128-142.

in, H. (2004) 'Corporate governance in the banking and financial services industries', Journal of Financial Intermediation, Vol. 13, No. 1, pp.1-5.

Mehran, H., Morrison, A.D. and Shapiro, J.D. (2011) Corporate Governance and Banks: What Have We Learned from the Financial Crisis?, FRB of New York Staff Report No. 502.

in, H. and Rosenberg, J.V. (2007) The Effect of Employee Stock Options on Bank Investment Choice, Borrowing, and Capital, FRB of New York Staff Report No. 305.

ck, K., Unal, H. and Yang, L. (2011) 'Pay for performance? CEO compensation and acquirer eturns in BHCs', Review of Financial Studies, Vol. 24, No. 2, pp.439-472.

Minton, B.A., Taillard, J. and Williamson, R.G. (2012) Board Composition, Risk Taking and Value: Evidence from Financial Firms, SSRN Working Paper Series.

ha, S. and Zamanb, M. (2015) 'Shari'Ah supervision, corporate governance and performance: :onventional vs. Islamic banks', Journal of Banking \& Finance, Forthcoming. iardino, A. and Plath, C. (2010) 'Risk governance at large banks: have any lessons been earned?', Journal of Risk Management in Financial Institutions, Vol. 3, No. 2, pp.116-123.

Muller-Kahle, M.I. and Lewellyn, K.B. (2011) 'Did board configuration matter? The case of US subprime lenders', Corporate Governance: An International Review, Vol. 19, No. 5, pp.405-417.

hy, K.J. (1985) 'Corporate performance and managerial remuneration: an empirical analysis', Iournal of Accounting \& Economics, Vol. 7, No. 1, pp.11-42.

Nguyen, D.D.L., Hagendorff, J. and Eshraghi, A. (2015) 'Which executive characteristics create value in banking? Evidence from appointment announcements', Corporate Governance: An International Review, Vol. 23, No. 2, pp.112-128.

Nielsen, S. and Huse, M. (2010) 'The contribution of women on boards of directors: going beyond the surface', Corporate Governance: An International Review, Vol. 18, No. 2, pp.136-148.

wola, W.K. (2010) 'Practice and standard of corporate governance in the Nigerian banking ndustry', International Journal of Economics \& Finance, Vol. 2, No. 4, p.178.

Organisation for Economic Co-operation and Development (OECD) (2004) Principles of Corporate Governance.

isation for Economic Co-operation and Development (OECD) (2006) Policy Brief on Corporate Jovernance of Banks in Asia, Asian Roundtable on Corporate Governance, June.

Organisation for Economic Co-operation and Development (OECD) (2015) Principles of Corporate Governance. 
Organisation for Economic Co-operation and Development OECD (2017) Corporate Governance Factbook.

, H. (2013) 'Bank monitoring incentives and optimal ABS', Journal of Financial Intermediation, Vol. 22, No. 1, pp.30-54.

, R. and Ford, D. (2012) Gender Quotas and Female Leadership, World Development Report, Jender Equality and Development, Background Paper.

Pathan, S. (2009) 'Strong boards, CEO power and bank risk-taking', Journal of Banking \& Finance, Vol. 33, No. 7, pp.1340-1350.

Pathan, S. and Faff, R. (2013) 'Does board structure in banks really affect their performance?', Journal of Banking \& Finance, Vol. 37, No. 5, pp.1573-1589.

n, S., Skully, M. and Wickramanayake, J. (2008) 'Reforms in Thai bank governance: the Iftermath of the Asian financial crisis', International Review of Financial Analysis, Vol. 17, No. 2, pp.345-362.

Pathan, S. and Skully, M. (2010) 'Endogenously structured boards of directors in banks', Journal of Banking \& Finance, Vol. 34, No. 7, pp.1590-1606.

Peni, E. and Vähämaa, S. (2012) 'Did good corporate governance improve bank performance during the financial crisis?', Journal of Financial Services Research, Vol. 41, Nos. 1-2, pp.19-35.

Peteraf, M.A. (1993) 'The cornerstones of competitive advantage: a resource-based view', Strategic Management Journal, Vol. 14, No. 3, pp.179-191.

Pi, L. and Timme, S.G. (1993) 'Corporate control and bank efficiency', Journal of Banking \& Finance, Vol. 17, No. 2, pp.515-530.

Pfeffer, J. (1972) 'Size and composition of corporate boards of directors: the organization and its environment', Administrative Science Quarterly,

Pfeffer, J. and Salancik, G.R. (2003) The External Co $>$ of Organizations: A Resource Dependence Perspective, $\longrightarrow$ rd University Press.

Prowse, S. (1998 porate Governance in East Asia: A Framework for Analysis, World Bank, Mimeo.

Pugliese, A. et al. (2009) 'Boards of directors' contribution to strategy: a literature review and research agenda', Corporate Governance: An International Review, Vol. 17, No. 3, pp.292-306.

Rachdi, H. and Ben Ameur, I.G. (2011) 'Board characteristics, performance and risk taking behaviour in Tunisian banks', International Journal of Business \& Management, Vol. 6, No. 6, p.88.

Rachdi, H., Trabelsi, M.A. and Trad, N. (2013) 'Banking governance and risk: the case of Tunisian conventional banks', Review of Economic Perspectives, Vol. 13, No. 4, pp.195-206.

Rajan, R. (2008) A View of the Liquidity Crisis, University of Chicago, Mimeo.

Rajan, U., Seru, A. and Vig, V. (2008) The Failure of Models that Predict Failure: Distance, Incentives and Defaults, Working Paper.

Rechner, P.L. and Dalton, D.R. (1991) 'CEO duality and organizational performance: a longitudinal analysis', Strategic Management Journal, Vol. 12, No. 2, pp.155-160.

Santos, J.A.C. and Rumble, A.S. (2006) 'The American keiretsu and universal banks: investing, voting and sitting on nonfinancials' corporate boards', Journal of Financial Economics, Vol. 8, No. 2, pp.419-454.

Sarbanes, P. (2002) 'Sarbanes-oxley act of 2002', The Public Company Accounting Reform and Investor Protection Act, US Congress, Washington DC.

Semenova, M. and Savchenko, P. (2015) 'Sitting on the fence: does having a 'dual-director'add to bank profitability?”, Applied Economics Letters, Vol. 22, No. 8, pp.654-657.

ad, C.T., de Haan, J. and Scholtens, B. (2010) 'The impact of bank ownership concentration on impaired loans and capital adequacy', Journal of Banking \& Finance, Vol. 34, No. 2, pp.399-408. 
Shleifer, A. and Vishny, R. (1997) 'A survey of corporate governance', The Journal of Finance, 2, pp.737-783.

C. (1998) 'The rise and fall of bank control in the United States: 1890-1939', American Economic Review, pp.1077-1093.

Simpson, W.G. and Gleason, A.E. (1999) 'Board structure, ownership, and financial distress in banking firms', International Review of Economics \& Finance, Vol. 8, No. 3, pp.281-292.

C.W. and Stulz, R.M. (1985) 'The determinants of firms' hedging policies', Journal of Financial \& Quantitative Analysis, Vol. 20, No. 4, pp.391-405.

Staikouras, P.K., Staikouras, C.K. and Agoraki, M-E.K. (2007) 'The effect of board size and composition on European bank performance', European Journal of Law \& Economics, Vol. 23, No. 1, pp.1-27.

Strøm, R.Ø., D'Espallier, B. and Mersland, R. (2014) 'Female leadership, performance, and governance in microfinance institutions', Journal of Banking \& Finance, $\longrightarrow$ 12, pp.60-75.

an, R.J. and Spong, K.R. (2007) 'Manager wealth concentration, owners ructure, and risk n commercial banks', Journal of Financial Intermediation, Vol. 16, No. 2, pp.229-248.

Terjesen, S., Sealy, R. and Singh, V. (2009) 'Women directors on corporate boards: a review and research agenda', Corporate Governance: An International Review, Vol. 17, No. 3, pp.320-337.

Thanassoulis, E. et al. (2011) 'Costs and efficiency of higher education institutions in England: a DEA analysis \& star', Journal of the Operational Research Society, Vol. 62, No. 7, pp.1282-1297.

Tian, G.Y. and Yang, F. (2014) 'CEO incentive compensation in US financial institutions', International Review of Financial Analysis, $\square$ i4, pp.64-75.

UK Government (2010) The UK Corporate Gove e Code, Financial Reporting Council, London.

Uwuigbe, O.R. and Fakile, A.S. (2012) 'The effects of board size on financial performance of banks: a study of listed banks in Nigeria', International Journal of Economics \& Finance, Vol. 4, No. 2, p.260.

zulen, E.P.M. (2013) Beneficial Ownership and Control: A Comparative Study Disclosure, 'nformation and Enforcement, No. 7, OECD Publishing.

; M. (2011) 'Advancing gender equality in economic decision-making', Conference on Equality Between Women and Men, European Commission, Brussels.

W.P. et al. (2008) 'The performance implications of relationship banking during macroeconomic zxpansion and contraction: a study of Japanese banks' social relationships and overseas expansion', Journal of International Business Studies, Vol. 39, No. 3, pp.406-427.

Wang, W-K., Lu, W-M. and Lin, Y-L. (2012) 'Does corporate governance play an important role in BHC performance? Evidence from the US', Economic Modelling, Vol. 29, No. 3, pp.751-760.

Wernerfelt, B. (1995) 'The resource-based view of the firm: ten years after', Strategic Management Journal, 7 , pp.171-171.

nan, H. 'The impact of management and board ownership on profitability in banks with lifferent strategies', Journal of Banking \& Finance, Vol. 35, No. 12, pp.3300-3318.

Williamson, O.E. (1979) 'Transaction-cost economics: the governance of contractual relations', Journal of Law \& Economics, $\longrightarrow 3-261$.

Williamson, O.E. (1981) 'The econ $\checkmark$ of organization: the transaction cost approach', American Journal of Sociology, $78-577$.

Williamson, O.E. (1983) '_ ization form, residual claimants, and corporate control', Journal of Law and Economics, $1-366$.

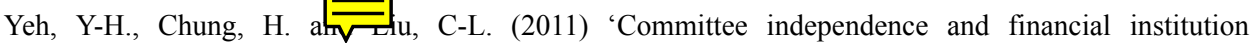
performance during the 2007-08 credit crunch: evidence from a multi-country study', Corporate Governance: An International Review, Vol. 19, No. 5, pp.437-458.

Yermack, D. (1996) 'Higher market valuation of companies with a small board of directors', Journal of Financial Economics, Vol. 40, No. 2, pp.185-211. 
Zagorchev, A. and Gao, L. (2015) 'Corporate governance and performance of financial institutions', Journal of Economics \& Business.

Zahra, S.A. and Pearce, J.A. (1989) 'Boards of directors and corporate financial performance: a review and integrative model', Journal of Management, Vol. 15, No. 2, pp.291-334. 